\title{
Modernismens \\ fire dimensioner
}

En æstetisk-eksistentiel

forstålsesramme for nyere poesi

Når jeg i det følgende vil beskæftige mig med begrebet lyrisk modernisme, har det to årsager. For det første vil jeg foretage en sondering blandt og diskussion af de mange forskellige definitioner, forståelsesrammer og associationer i forhold til begrebet, som man finder inden for litteraturvidenskaben. For det andet vil jeg fors $\emptyset$ ge med udgangspunkt i en beskrivelse af fire æstetisk-eksistentielle kategorier eller dimensioner at fremlægge en analytisk og fortolkningsmæssigt frugtbar bestemmelse af termen.

\section{Lyrisk modernisme mellem beslagtede begreber}

Begrebet modernisme er blandt de mest komplekse og omdiskuterede inden for litteraturvidenskaben. Der hersker et vildnis af forskellige opfattelser af begrebet med udgangspunkt i en række forskellige litterære, filosofiske og sociologiske teoridannelser, og forvirringen bliver ikke mindre af, at udtrykket har meget forskellig betydning og udbredelse, hvis man går til henholdsvis nordisk, angelsaksisk, germansk og romansk tradition. ${ }^{1}$ Man kan generelt iagttage, hvordan termen modernisme er gledet sammen med eller har udspaltet sig i en lang række underbegreber. I mangfoldige værker er det vilkårligt eller uigennemskueligt, hvornår der tales om modernisme, moderne og modernitet, hvor grænserne går mellem modernisme, postmodernisme, præmodernisme, neomodernisme og højmodernisme, og endelig hvad der adskiller lyrisk modernisme fra modernisme inden for andre kunstarter og litterære genrer. Jeg vil derfor indledende prøve at afgrænse begrebet lyrisk modernisme i forhold til andre beslægtede termer.

At komme med en entydig definition på begrebet modernisme er næppe muligt. I afhandlingen Modernism och individualitet (1986) anfører Peter Luthersson, at ansvaret for, hvordan man definerer termen modernisme, altid må 
ligge hos den enkelte forsker, der dog er underlagt to krav. Disse er, at hans modernismebegreb for det første skal tage udgangspunkt i, at forskeren »antager eksistensen af og studerer en entitet, som kaldes »modernisme««, og for det andet, at han »relaterer sine betragtninger til dem som tidligere forskere og kritikere har gjort. $\ll^{2}$ Det er naturligvis dog langtfra ligegyldigt, hvilke referencer inden for forskningstraditionen, der anvendes i forhold til et tekstobjekt, som man ønsker at anskue ud fra synsvinklen »modernisme. «I det følgende vil det fremgå, at der findes mange bestemmelser af begrebet modernisme, der ud fra denne artikels synsvinkel må anses for at være meget lidt produktive.

Begrebshistorisk kan udtrykket moderne spores tilbage til det latinske »modernus « fra senantikken i det 5. århundrede hos Gelasius, og det har fra det 18. århundredes klassicisme og fremefter været et vigtigt slagord i den litterære debat i Europa. ${ }^{3}$ Hos Montesquieu og Diderot hentyder termen moderne til fremskridtstro og kulturoptimisme. Hos den romantiske bevægelses forløbere Herder og Rousseau får den en helt anden negativ værdi, idet den forbindes med en åndelig degeneration inden for samtidens kunstpoesi, hvis modsætning er de fjerne tiders herlige naturpoesi. Man træffer den samme modsætning mellem forskellige valueringer af begrebet hos på den ene side Heines »Det unge Tyskland « i 1830'erne og Brandes Det moderne Gennembruds Mand fra 1883, og på den anden side Baudelaire og de franske symbolister. Hos de første er det moderne forbundet med en antiidealistisk emancipatorisk bevægelse og at »sætte Problemer under Debat «, mens det hos Baudelaire og de franske symbolister hænger sammen med en nihilistisk holdning og et helt igennem fremmedgjort og fjendtligt forhold til civilisationen.

Hermed er vi fremme ved Baudelaires centrale begreb modernitet, hvorved han forstår den storbyvirkelighed, som outcast-digteren konfronteres med, og som vækker digterens særlige evne til at se en hemmelig skønhed i det forfaldne, dekadente og hæslige. Betegnelsen modernitet anvendes imidlertid også i en langt bredere betydning end Baudelaires æstetisk orienterede, som det f.eks. sker blandt Frankfurterskolens filosoffer, sociologer og litterater, hvor der med udtrykket som regel menes de konkrete historiske ombrydninger som helhed, der har fundet sted siden midten af 1700-tallet.

På samme måde hersker der forvirring omkring begrebet modernisme, hvis indhold ofte afhænger af, hvilken opfattelse man har af begrebet moderne. Første gang ordet modernisme optræder i et dansk litteraturhistorisk værk, er i Vilhelm Andersens J.P. Jacobsen-afhandling fra 1905, hvor det nærmest sættes lig med hele den dengang moderne litteratur, d.v.s. digtningen efter romantikken. ${ }^{4} \mathrm{Og}$ ved det 20. århundredes udgang i antologien Spurvesol fra 1989 kan man læse, at »alle de kunstretninger, der bygger på en nedrivning af gamle forestillinger og skabelsen af helt moderne, kaldes under ét modernisme. $\ll^{5} \mathrm{De}$ 
to eksempler illustrerer en af de mest almindelige måder, hvorpå begreberne moderne og modernisme har mistet enhver relevans, nemlig ved bevidstløst at blive identificeret med det til enhver tid »nye. $\ll^{6}$

En anden årsag til divergensen i opfattelsen af modernismetermen er, at man ofte har taget patent på og annekteret betegnelsen til brug for en bestemt tilstand i et bestemt land, såsom angelsaksisk litteratur fra det 20. århundredes første trediedel (»Modernism «), spansk litteratur fra 1880'erne (»modernismo«) eller dansk litteratur fra begyndelsen af 1960'erne (»modernisme«). I Danmark bliver det først kutyme med en bred, international modernismeterm efter Poul Borums Poetisk modernisme fra 1966. I denne bog bekæmpes, hvad der kaldes »litteraturpolitisk provinsialisme «, 7 på et tidspunkt, hvor fokus i dansk litteraturkritik i høj grad er rettet mod lanceringen af nye modernistiske faser og generationer i den nationale litteratur. ${ }^{8}$ Man kommer dog ikke i Borums bog nærmere en generel bestemmelse af, hvad modernistisk lyrik er, når man undtager en kort omtale af Baudelaires modernitetsbegreb. ${ }^{9}$

Andre har med udgangspunkt i en mere teoretisk diskurs fors $\emptyset \mathrm{gt}$ at definere begreberne moderne, modernitet og modernisme. Den nykritisk funderede, angelsaksiske litteraturvidenskabs bedste bud på forskellen på de tre etiketter, finder man nok i Stephen Spenders The Struggle of the Modern (1963) og Graham Houghs artikel »The Modernist Lyric« (1976). Houghs formulering lyder lakonisk: »Det moderne er et spørgsmål om periode og historisk fase; det modernistiske et spørgsmål om kunst og teknik, en særegen drejning af den poetiske optik « (»a peculiar twist of vision «). ${ }^{10}$ Som eksempel på denne distinktion mellem moderne og modernisme, der altså hviler på en rent poesiog åndshistorisk betragtningsmåde, anfører Hough, at Baudelaire er den første moderne digter, da han, som den »poète maudit« han er, inkarnerer en række sociale og ideologiske træk ved den moderne digtereksistens. Men Baudelaire er samtidig ikke modernist, da hans formsprog er for traditionelt og - finder Hough - »ofte minder os om Racine. « Den første modernist er derimod Rimbaud. Her finder vi »et nyt sprog og en ny poetisk diktion, der modsvarer ændringen i digterrollen. $\ll^{11}$

Går vi til Frankfurterskolens æstetisk-sociologisk orienterede betragtning af modernismen (Benjamin, Adorno), som bl.a. er inspirationskilde for Per Stounbjergs artikel »Det ustadiges æstetik «, er der ikke nogen afgørende divergens i forhold til Houghs opfattelse af begreberne moderne og modernisme, når man ser bort fra, at termen moderne her efter marxismens dialektisk materialistiske betragtningsmåde er opdelt $i$ henholdsvis en materiel og en åndelig del benævnt moderniteten og det moderne. Mens moderniteten er den historiske virkelighed forstået som konkrete $\varnothing$ konomiske, sociale og politiske forhold, tilhører det moderne samfundets overbygning, d.v.s. det er en »histo- 
risk specifik måde at tænke på. «12 Modernismen er da en af de litterære retninger, der forholder sig til moderniteten, og er styret af de principper, som det moderne er bærer af. Stounbjerg peger imidlertid ikke som Hough på enkeltdigtere fra den moderne epoke såsom Baudelaire, som ikke er modernistiske, men derimod på hele retninger. Det siges:

»De litterære strømninger, der forholder sig til moderniteten - romantikken, naturalismen, realismen f.eks. - kan betegnes som moderne. Modernismen er en del af den moderne litteratur, men al moderne litteratur er ikke modernistisk. Modernismen er således ikke kun defineret ved sin ballast af moderne erfaringer, men også ved dens formsprog. I denne forstand er modernismen også norm. $\ll^{13}$

I Stounbjergs ræsonnement er der tydeligvis to svagheder. For det første er det diskutabelt, om modernismebegrebet kan sidestilles med andre litterære stilog periodebetegnelser. For det andet er det spørgsmålet, om modernismebegrebet ikke mister en hel del af sin relevans, når det anskues helt uden relation til genrer og kunstarter.

Med hensyn til det første argumenterer Bradbury \& McFarlane i Modernism for det synspunkt, at »Modernism « indtager en særstilling i forhold til andre litterære ismer, idet den er en mere overordnet og kompleks kategori. Modsat modernisme er begreber som romantik ${ }^{14}$ og naturalisme ofte blevet defineret som modsætninger i den hegelianske tese-antitese-model, som det f.eks. kendes fra Brandes Hovedstrømninger (1871) og Stephen Spenders The Struggle of the Modern (1963), hvor litteraturen udvikler sig som en kamp mellem rationalt, objektivistisk orienterede litterære strømninger og irrationelt, subjektivistisk dominerede. Bradbury \& McFarlane siger rammende:

»Man må forestille sig, at den periode, vi kalder det moderne, hverken viser os rehabiliteringen af det irrationelle efter en periode af realisme, eller det modsatte, en klassicistisk periode efter en romantisk, men derimod en blanding af alle disse muligheder: syntesen, forsoningen, sammenvoksningen, fusionen - måske en exceptionel eksplosiv fusion - af fornuft og ufornuft, intellekt og følelse, subjektivt og objektivt.« ${ }^{15}$

Når disse betragtninger er anført, er det for at understrege det synspunkt, at modernismebegrebet ikke, som etiketterne naturalisme og romantik er blevet det, kan eller bør bestemmes ud fra idéhistoriske kategorier eller fixeres tidsmæssigt til en kort afgrænset epoke. 
Det andet problematiske punkt i Stounbjergs modernismebegreb angår dets manglende relation til bestemte kunstarter og genrer. ${ }^{16}$ Det er værd at notere sig, at kun to kunstarter, nemlig maleriet og lyrikken, synes at operere med begrebet modernisme, som en helt central og uomgængelig term. ${ }^{17}$ Inden for henholdsvis prosa, drama, musik, skulpturkunst og arkitektur anvendes modernismebegrebet også, men det har langtfra den samme altafgørende betydning, som det har inden for malerkunst og lyrik, hvor modernisme i de sidste 100 år har været opfattet som det helt essentielle begreb i forhold til kunstarten. Alene ud fra denne betragtning synes det diskutabelt, om der kan drages paralleller mellem det, man kalder modernisme inden for forskellige kunstarter og genrer. (Hvad er f.eks. lighederne mellem et abstrakt maleri af Kandinsky, en funktionalistisk skyskraber fra 20ernes New York, en komposition af Stravinsky, et digt af Gustaf Munch-Petersen og et skuespil af Beckett?)

Betragter vi de litterære genrer er det karakteristisk, at modernismebegrebet har haft vanskeligt ved at slå an som analytisk kategori inden for epikken. En vigtig årsag til dette er formodentlig, at genrens norm - beretningen af et handlingsforløb i tid og rum - i sig selv er sammenfaldende med visse træk i de fleste definitioner af begrebet realisme, der ofte opfattes som en polær modsætning til modernisme. Modernistisk prosa bliver på denne vis en negativt defineret term, d.v.s. den forstås som en afvigelse fra en realismenorm. $\mathrm{Og}$ på grund af de store overlapninger i definitionerne af de litterære begreber epik og realisme, bliver modernistisk prosa identificeret som tekster, hvori tidsfølge, struktureret rum og fortællerposition fremtræder som komplekse og svært gennemskuelige kategorier. Hermed får man imidlertid en ret intetsigende bestemmelse af, hvad modernistisk prosa er. Det bliver et spørgsmål om, hvorvidt der i teksterne er træk, der normalt tilskrives de to andre litterære hovedgenrer, nemlig den lyriske eller den dramatiske. Et eksempel på en sådan bestemmelse af prosamodernisme er Søren Baggesens afsnit fra Modernismen i dansk litteratur (1967), hvor det siges, at »den modernistiske roman betvivler holdbarheden af den traditionelle realismes grænser mellem person og omverden, mellem bevidst og ubevidst og mellem før, nu og efter. $\aleph^{18}$

I de seneste årtier har man i litteraturvidenskaben set et mere kritisk syn på dikotomien realisme-modernisme. Med realismeteoriernes opblomstring i 1970ernes danske litteraturkritik blev det tydeligt, at det ofte ikke var muligt at finde en fællesnævner mellem forskellige realismebegreber (Lukács, Auerbach, Møller Kristensen, Bang etc.). Og i kølvandet på 1980ernes danske dekonstruktion forekommer der adskillige eksempler på en total afvisning af realismebegrebets relevans, såsom lederartiklen i KRITIK 121, hvor redaktørerne Frederik Stjernfelt og Nils Gunder Hansen skriver: »Realismen er således ikke nogen norm. Den er en fænomenologisk forudsætning i enhver fortolkning af 
hvadsomhelst, herunder kunst og litteratur. Skal der udkæmpes stridigheder, bliver det mellem realismer.«

I det mest overbevisende eksempel i dansk litteraturkritik med hensyn til at definere, hvad modernisme inden for prosa er, nemlig Per Stounbjergs »Det ustadiges æstetik«, er der da også tale om et gennemført forsøg på at dekonstruere dikotomien realisme-modernisme:

»Det er altså en konventionelt indsnævret opfattelse af enten kunstens form for virkelighedsgengivelse eller af livet, der fraskriver modernismen mimetiske kvaliteter. Lad os omdefinere problematikken. Der er måske snarere tale om, at modernismen dæmper referencen til en ydre, objektiv virkelighed med faste konturer. At den giver afkald på traditionelle realitetetseffekter og referentielle illusioner til fordel for en ekspressiv æstetik. Lige så lidt som modernismen er antimimetisk er den rent ikke-referentiel. Snarere er der tale om, at referencerne, forholdet mellem værk og verden, bliver urolige og problematiske. Modernismen er en instabilitetens æstetik. $\ll^{19}$

Når Stounbjergs bestemmelse er ligeså fortræffelig i forhold til prosa, som den er utilstrækkelig i forhold til lyrik, skyldes det, at problemer omkring »det referentielle«, »mimesis « og »realisme «, som udgør kernen i Stounbjergs diskussion og i en mængde litteraturteorier med afsæt i prosa, jo netop er ulige mere relevante for en diskussion af prosamodernisme end for lyrisk modernisme. Hvad der er specifikke træk for en del af prosaen fra de sidste 100 år (»dæmper referencen til en ydre, objektiv virkelighed med faste konturer«, "giver afkald på traditionelle realitetseffekter og referentielle illusioner « etc.) er nemlig en selvfølge for stort set al kvalitetslyrik siden barokken.

En anden forklaring på, at begrebet modernisme kun i svag grad har vundet indpas i forhold til prosa, ligger nok i, at man i stedet inden for de sidste 30 år - især i den angelsaksiske litteraturkritik - har reserveret betegnelsen postmodernisme til den eksperimenterende prosa efter 1945, mens modernisme er blevet brugt som betegnelse for en lille gruppe litterære koryfæer fra mellemkrigstiden (Proust, Joyce, Faulkner, Woolf, Kafka etc.). Blandt de mange litteraturteoretiske værker, der anvender betegnelsen postmodernisme i forhold til prosa fra de sidste ca. 20 år, kan nævnes Linda Hutcheons A Poetics of Postmodernism (1988), Brian McHale Postmodernist Fiction (1987) og Patricia Wauchs Practising Postmodernism / Reading Modernism (1992).

Modsat anvendelsen af udtrykket postmodernisme inden for prosa er der til gengæld kun ganske få litteraturvidenskabelige afhandlinger, der behandler fænomenet postmodernistisk poesi (hvis vi ser bort fra de postmodernistiske 
træk, der fremhæves i 1960ernes amerikanske litteraturkritik (Sontag, Levin, Meyer, Barth m.fl.), nemlig det eklektiske forhold til den litterære tradition og sprængningen af det traditionelle værkbegreb). Et enkelt eksempel på en konsekvent anvendelse af postmodernismebegrebet i forhold til lyrik er Joseph M. Contes Unending Design. The Forms of Postmodern Poetry (1991). Det er dog tvivlsomt om denne afhandling fanger noget centralt i retning af en nyorientering inden for poesien fra de seneste 20 år. Efter Contes opfattelse ser man i ny poesi - og Contes eksempelmateriale er her begrænset til en håndfuld amerikanske lyrikere, såsom John Ashbery og John Cage - en sammenhæng mellem på den ene side moderne naturvidenskabs kaosteori og på den anden side en række lyriske værker, hvis komposition hviler på uafsluttetheds-, gentagelses- og tilfældighedsprincipper. At Contes forståelsesramme for postmodernistisk lyrik har visse svagheder, er oplagt, hvis man bemærker, at lyriske tekster med de nævnte karakteristika har eksisteret i rig målestok i henved et århundrede hos eksempelvis Rimbaud og Lautréamont i 1870erne, Marinettis futuristiske proselytter i 1910erne og Bretons surrealistkreds i 1930erne.

Snarere end som Conte at forsøge at bestemme en postmodernistisk poesi, der adskiller sig markant fra en modernistisk, er der nok mere fornuft $\mathrm{i}$ at hælde til Frank Kermodes tese fra »Modernisms « (1968), hvor det anføres, at det, som andre har benævnt »Postmodernism « i forfatterskaberskaber som Cages og Burroughs, er en videreførelse af tendenser fra mellemkrigstidens avantgardepoesi inden for bl.a. dadaisme og surrealisme. Polemisk taler Kermode i denne sammenhæng om $»$ Neomodernism $\ll^{20}$ i stedet for som andre om »Postmodernism. $\ll^{21}$

Efter denne sondering i, hvorledes begrebet modernisme kan afgrænses i forhold til en række beslægtede begreber, vil jeg gå over til at se nærmere på, hvad termen lyrisk modernisme egentlig dækker. Groft sagt har der hersket to forskellige retninger med hensyn til at definere modernismen inden for poesi, nemlig en der anskuer termen historisk og ofte i relation til nationalt afgrænsede litterære strømninger, og en der anlægger et transhistorisk perspektiv, hvor man fors $\emptyset$ ger at bestemme et æstetisk og eksistentielt fællespræg. Først den litteraturhistoriske vinkel.

\section{Epokal modernismebestemmelse}

Tendensen til at forsøge at afgrænse den modernistiske lyrik som en periode har været særdeles udpræget. Der eksisterer groft sagt tre forskellige grundholdninger til dette spørgsmål. Den første tysk-fransk-skandinavisk orienterede retning fastsætter modernismens begyndelse til den franske symbolistiske 
digtning fra midten af 1800-tallet og Baudelaires Fleurs du Mal fra 1857. Det andet synspunkt består i, at den modernistiske lyriks rødder skal søges så langt tilbage som i den romantiske digtning fra omkring år 1800 og forfægtes af en række vidt forskellige angelsaksiske litteraturforskere såsom M.H. Abrams, Northrop Frye, Paul de Man og Harold Bloom. Og endelig består den sidste inden for angelsaksisk forskning særdeles dominerende opfattelse - i et syn på den modernistiske poesi som noget, hvis begyndelse bør dateres til det sidste årti af det 19. århundrede.

Et par af de utallige værker, der som grundantagelse har opfattelsen af Baudelaire som den første modernistiske digter er Hugo Friedrichs Strukturen $i$ moderne lyrik (1956), Kjell Espmarks Att översätta själan (1976), Poul Borums Poetisk modernisme (1966), Erik A. Nielsens Modernismen i dansk lyrik 1870-1970 (1976) og Bo Hakon Jørgensen Symbolismen - eller jegets orfiske forklaring (1993). I enkelte tilfælde som i Torben Brostrøms Labyrint og arabesk (1967) og Ti års kritik (1975) argumenteres der for, at der også findes »en anden modernistisk tradition, som udgår fra Baudelaires samtidige Walt Whitman, hvem Friedrich kun har en sidebemærkning tilovers for. En poesi, hvis universalisme ikke er tragisk, men har de nye muligheders universalisme. $\ll^{22}$ Men stadig opretholder denne kritik af den friedrichske modernismebestemmelse, der jo i praksis sætter det modernistiske skelsår til to år tidligere, nemlig til udgivelsen af Whitmans Leaves of Grass (1855), et skarpt skel mellem det tidlige 1800-tals romantik og det sene 1800-tals symbolisme/modernisme. Også Jørgen Sonnes antologi De første moderne (1983), der foruden Baudelaire, Rimbaud, Mallarmé og Lautréamont behandler den allerede i 1855 afdøde, desperadodigter Gérard de Nerval, er et forsøg på at rokke ved den grundmurede litteraturhistoriske konstruktion, der med Poul Borums ord fastslår, at »Baudelaire er den første og den største moderne digter. $\ll^{23}$

Inden for dansk litteraturhistorie har myten om en portalagtig indgang til den moderne poesi med en monumental Baudelaire-agtig skikkelse været gældende siden 1960erne. Navnet er her J.P. Jacobsen, hvis stilling som alt andet end positivist og darwinist har været antydet, siden Brandes selv beskrev ham som »vor sjælfuldste og mest digteriske Særling. « ${ }^{24}$ Og da Aage Henriksenskolen og senere ideologikritikken tager fat på dekonstruktionen af Vilhelm Andersens litteraturhistorie, er tendensen til at placere Jacobsen som modernist en tilbagevendende begivenhed. Erik A. Nielsen skriver om »sværdet igennem nattens hjerte « $\mathrm{i} »$ Arabesk til en Haandtegning af Michelangelo« (1874), at »med dette sværd skæres dansk modernistisk digtning fri fra det borgerlige liv. $\ll^{25}$ Peer E. Sørensen siger i 1976 om det samme digt, at Jacobsens $\gg$ refleksioner i deres specifikke form er sammenfaldende med tendenserne inden for den europæiske symbolisme/modernisme. ${ }^{26} \mathrm{Og}$ Poul Borum proklamerer i 1969 lakonisk: »Modernismen i Danmark er begyndt.«27 
Man har i dansk litteraturforskning generelt lagt vægt på, at der er et betydeligt skisma mellem en romantisk digtning fra det tidlige 1800-tal og en symbolistisk-modernistisk fra det sene 1800-tal og fremefter, og der har været en tendens til simpelthen at definere symbolismen/modernismen som en modsætning til eller reaktion på romantikken.

Modsat dette synspunkt har der i angelsaksisk litteraturforskning siden 1950erne været en tendens til at vægte en kontinuitet i en kunstnerisk udvikling helt tilbage fra romantikken over symbolisme og frem til nutidens modernisme. I argumentationen for, at man skal søge den moderne kunsts rødder tilbage i slutningen af det 18. århundrede, kan man hente støtte hos så forskellige litterater som Northrop Frye, M.H. Abrams og Paul de Man. Frye diagnosticerer det moderne i den romantiske litteratur i dens brug af mytologi, der anvendes løsrevet fra enhver form for dogmatiske systemer og forvaltes som led i skabelsen af en helt personlig omverdenstolkning, mens Abrams specielt hæfter sig ved de klare paralleller mellem den ekspressive kunstnerrolle og »imagination «-begrebet i de to epoker. Og endelig ser Paul de Man romantikernes modernitet i deres retoriske bevidsthed, hvorved han forstår den artistiske dimension, som deres tekster tilføres i kraft af, at kunstneren har gennemskuet sprogets manglende evne til at repræsentere såvel den indre/sjælelige som den ydre/materielle verden. ${ }^{28}$

Også den angelsaksisk orienterede Bo Green Jensen har som en af de få danskere i sit essay »Den stadige blomstring og den tabte epifani« lanceret ideen om, at det kan være mere frugtbart at se på sammenhængene mellem det tidlige 1800-tals og nutidens digtning end på forskellene. En central formulering lyder:

»Min hypotese er slet og ret den, at romantikken ikke »ophører « på et eller andet tidspunkt i det nittende århundrede, men at dens transcendentale og/eller »sorte « strømninger op igennem århundredet og ind i vort eget metamorforiseres i stadigt mørkere, mere komplekse former, mønstre og motiver. At symbolismen og sidenhen modernismen snarere end at være reaktioner på eller imod romantikken, kan betragtes som henholdsvis anden og tredje fase af denne. $\ll^{29}$

Imidlertid er det karakteristisk, at den absolutte mainstream inden for angelsaksisk modernismeforskning opfatter »modernism « som en afgrænset litteraturhistorisk epoke af langt nyere dato. I megen angelsaksisk litteratur- og kunstkritik ses kunsten fra det 20. århundrede som epokalt forskellig fra al tidligere kunst, idet man lokaliserer et voldsomt og dramatisk brud til tiden omkring århundredeskiftet. Man kan f.eks. gå til kunsthistorikeren Herbert Reads Art Now (1933), i hvilken det siges: 
»Hvad vi nu er vidne til, er ikke en logisk udvikling inden for malerkunsten i Europa, ikke engang en udvikling, i forhold til hvilken man finder nogen historisk parallel, men derimod et abrupt brud med al tradition. Målet for fem århundreders stræben inden for europæisk kunst bliver åbenlyst fornægtet. $\ll^{30}$

Den engelske litterat C.S. Lewis har lignende deklamatoriske vendinger: »Jeg forstår ikke, at nogen kan betvivle, at moderne poesi ikke blot har større nyhedsværdi end nogen anden »ny poesi «, men er ny på en helt ny måde, næsten $i$ en ny dimension. $\ll^{31}-$ Andre skribenter har været mere optaget af at bestemme et præcist årstal for modernismens gennembrud. I en sådan mytekonstruerende bestræbelse har man bl.a. henholdt sig til en række skønlitterære forfattere, der har haft nogle alt andet end objektive og gennemreflekterede bud på, hvornår modernismen starter. Det gælder f.eks. Virginia Woolfs udsagn: »I december måned 1910 eller deromkring ændrede den menneskelige natur sig ... Alle menneskelige relationer forandrede sig... Og da de menneskelige relationer ændrede sig, ændrede religion, moral, politik og litteratur sig også. « ${ }^{32}$

Hos D.H. Lawrence træffer man en lignende statement: »Den gamle verden gik under i 1915.« Og der optræder i det hele taget i den angelsaksiske forskningstradition en mængde bud på, hvornår den litteraturhistoriske epoke »Modernism « bryder igennem. Hos A. Alvarez er perioden snævert centreret omkring forfatterskaberne Pound, Eliot, Joyce og Kafka, mens de altafgørende forfattere hos Stephen Spender (1963) - foruden Pound, Eliot og Joyce - er Yeats, Gide, Valéry og Mann. ${ }^{33}$ Mere årstalsfixeret er Frank Kermode (1968), der anfører at »enhver der overvejer, hvad modernisme er, gør klogt i at se nærmere på perioden fra 1907 til 1925. $\aleph^{34}$ Det samme gælder Richard Ellmann (1960), der føler trang til at korrigere den førnævnte udtalelse af Virginia Woolf: »Jeg vil foreslå år 1900 som startår for modernismen, da dette årstal er både mere bekvemt og mere nøjagtigt end Virginia Woolfs $1910 . \ll^{35}$ Hos Harry Levin (1966) har det specielt interesse »at identificere det modernistiske år (»the modernist year«) ${ }^{36}$ Dette fastsættes til 1922 på grund af årets koncentration af vigtige litterære udgivelser af Eliot (The Waste Land), Joyce (Ulysses), Rilke (Duino Elegier) og Woolf (Jacob's Room).

Essensen af alle disse modernismebestemmelser er naturligvis, at der er tale om en for nærsynet fokusering på det angelsaksiske områdes litteratur. Selv i den bredeste og mest alsidige af alle angelsaksiske modernismefremstillinger, antologien Bradbury \& McFarlanes Modernism. A guide to European Literature 1890-1930, har man en gennemført anglofil synsvinkel, hvor man omtaler tre forskellige og ligeværdige litterære traditioner nemlig »europæisk, engelsk og amerikansk. $\ll^{37}$ Modernism henholder sig i sin modernismebestemmelse desuden næsten alene til angelsaksisk forskningslitteratur, omend man 
i værket finder et lidt bredere perspektiv end vanligt $i$ angelsaksisk forskning, hvilket bl.a. giver sig udtryk i, at man ud fra betragtninger af fransk og tysk litteratur har sat modernismens gennembrud så langt tilbage som til 1890.

Argumentationen for, at dette eller hint årstal er et skelsår for den modernistiske litteratur, står oftest slet ikke i forhold til det emotionelle engagement, der investeres i synspunktet. For Virginia Woolf og de, der annekterer hendes opfattelse af 1910 som et banebrydende årstal, ligger der naturligvis ikke en rationel årsagsforklaring $i$, at gennembruddet for det moderne falder sammen med Edward VII's død. Dødsfaldet fungerer blot som symbolsk indikator på, at »det nye « er overordentlig betydningsfuldt.

I Bradbury \& McFarlanes Modernism argumenteres der mere grundigt for det synspunkt, at litteraturen skifter afgørende karakter fra 1890. Dette begrundes med udgangspunkt i nogle idéhistoriske betragtninger omkring fin-desiècle-fænomenet. Den vestlige kulturkreds' historiesyn ændres afgørende, hævdes det, i retning af en apokalyptisk livsforståelse, hvor fornemmelsen af fremadrettet kvalitativ udvikling afløses af en gennemgribende krisestemning med revolution og undergang som essentielle kategorier. Fin-de-siècle-atmosfæren er kort og godt, påstår Modernism, den logiske og afgørende forklaring på modernismens vægtning af epifanien:

»Konsekvensen af dette apokalyptiske sammenbrud af orden forklarer meget af modernismen. Det belyser symbolisternes fors $\varnothing \mathrm{g}$ på at transcendere den historiske udvikling ved hjælp den tidløse kunstneriske åbenbaring: Kunstneren sætter, som Scott Fitzgeralds Gatsby, tiden i stå og ser skønhed, form, drøm. $\ll^{38}$

Bradbury \& McFarlanes iagttagelse med hensyn til epifanitrækket ved modernismen er naturligvis korrekt. At det specielt har at gøre med en fin-de-sièclestemning er det derimod nok ikke, for vi finder jo fænomenet talrige steder tidligere i litteraturen. Det gælder ikke bare de franske symbolister Baudelaire, Verlaine, Rimbaud og Mallarmé, men det er også markant hos en lang række romantiske digtere.

Ligeså diskutabel er Bradbury \& McFarlanes og andre angelsaksiske litteraters fastsættelse af et afsluttende årstal for den modernistiske litteratur. Når 1930 fremhæves, forklares det ved, at de intellektuelle på dette tidspunkt igen begynder at betragte historien ud fra en $\varnothing$ konomisk og politisk synsvinkel:

»De afgørende forudsætninger for modernismen er til stede indtil efter 2. verdenskrig eller i alt fald indtil 1930. Derefter synes det som om en række modernistiske træk ved kunsten forsvinder eller ændrer sig, i og med at historien i højere grad bliver aktuel for de intellektuelle, ... samt 
at verdensdepressionen i stigende grad bringer politisk og $\varnothing$ konomisk determinisme ind i de intellektuelles verden. $\ll^{39}$

Igen står det klart, at vi ikke bare har at gøre med en række alt for løse åndhistoriske generaliseringer, men først og fremmest et alt for snævert angelsaksisk perspektiv. Vurderer man f.eks. Bradbury \& McFarlanes påstand i forhold til den nordiske modernistiske lyrik er det oplagt, at den er fejlagtig. Den periode i det 20. århundredes nordiske modernisme, hvor epifanierne florerer, den apokalyptiske stemning er på sit højeste og det realhistoriske engagement er meget lille, ligger klart senere end Bradbury \& McFarlanes modernistiske epoke, nemlig i henholdsvis svensk 40-talslyrik og dansk Heretica-digtning.

Det kan samlet slåes fast, at de mange, der har forsøgt at definere den modernistiske lyrik som en tidsmæssigt afgrænset epoke, i de fleste tilfælde fokuserer snævert på bestemte digtere, stilarter eller nationaliteter. Mest rimelig er uden tvivl den helt åbne forståelse af den modernistiske epoke, som man finder hos eksempelvis Frye, Abrams, de Man og Bloom, hvor man fastholder, at fænomenet findes fra omkring $1800 \mathrm{og}$ frem. Med denne sprængning af gængse opfattelser af den modernistiske lyrik som noget, der kan afgrænses epokalt, siges der så til gengæld intet præcist om den. Vi vil derfor gå over til at prøve at anskue lyrisk modernisme som en æstetisk-eksistentiel kategori.

\section{AEstetisk-eksistentiel modernismebestemmelse}

I forsøget på i det følgende at opstille en række æstetisk-eksistentielle kategorier, som kan indfange centrale træk ved lyrisk modernisme, vil jeg tage udgangspunkt i værker af tre af de teoretikere, som har haft størst betydning for modernismeforståelsen i Danmark og det фvrige Europa. Det drejer sig om den spanske kulturkritiker og filosof José Ortega y Gasséts Menneskets fordrivelse fra kunsten (1925), den formalistisk orienterede tyske litterat Hugo Friedrichs Strukturen i moderne lyrik (1956) og den dansk konfrontationsmodernistiske bannerfører Torben Brostrøms Modernisme før og nu (1983). At disse tre værker er udvalgt, har tre årsager. For det første har vi ved at vælge disse tre teoretikere, hvis baggrund med hensyn til såvel nationalitet, tidsepoke og teoretisk udgangspunkt er meget forskellig, en vis sikkerhed for, at de træk ved lyrisk modernisme, som vil blive fremanalyseret, har generel udbredelse. For det andet giver divergenserne mellem teoretikerne en mulighed for at betragte og diskutere nuancer ved de kategorier, der vil blive fremdraget. Og for det tredje er det interessant at notere sig, hvordan de tre værker kan læses som milepæle i en æstetikhistorisk udvikling, hvor man i tiden fra 1925 
over 1956 til 1983 kan iagttage en stadig voksende konsolidering af og optimistisk selvforståelse inden for den modernistiske kunsttradition.

I Menneskets fordrivelse fra kunsten er Ortega y Gasséts ærinde ud fra en kulturhistorisk synsvinkel at diagnosticere en krise ved den avantgardistiske kunst. Ortega y Gassét springer i sine analyser ubesværet mellem forskellige kunstarter, mellem fortid og nutid og mellem forskellige nationaliteters æstetiske værker, og resultatet er en række suggestive karakteristikker og skarpsindige synteser. Interessant er y Gasséts ambivalens. I Menneskets fordrivelse fra kunsten indtages på den ene side en skeptisk og distanceret holdning over for den moderne kunst, der ikke tilkendes konstruktive erkendelsesmæssige potentialer, og som bl.a. konsekvent kaldes »en ting«. På den anden side er der en dyb fascination af det moderne kunstværk, som hans energiske diktion og sansemættede billedsprog afslører i udtryk som »dunkle verdener«, »besynderlige fremmede «, »brændte de skibe « og »menneskelige flora og fauna.« Det følgende citat af y Gassét kan danne udgangspunkt for en generel bestemmelse af hans holdning:

»At glæde sig over og have medlidenhed med de skæbner, som kunstværket beretter om eller fremstiller, ligger milevidt fra den sande æstetiske nydelse. Ja, at beskæftige sig med værkets menneskelige indhold er principielt uforeneligt med den æstetiske nydelse i egentlig forstand.

... Med det nye billedes genstande er ethvert samliv udelukket. Da maleren tog udseendet af oplevet virkelighed fra dem, kastede han broen af og brændte de skibe, som kunne have ført os tilbage til vores vante omgivelser. Han spærrer os inde i dunkle verdener, han tvinger os til at omgås ting, som man ikke kan omgås på menneskelig måde... Vi må skabe eller finde en ny livsholdning... Mallarmé var det første menneske i det forgangne århundrede, som ville være digter. Han sagde, at han »afslog at gøre brug af det naturlige materiale.« Han skabte små lyriske ting, som ikke forekom i den menneskelige flora og fauna. $\ll^{40}$

Også i den 30 år senere Strukturen i moderne lyrik er der en udpræget tendens til at markere en analytisk distance i forhold til den moderne lyrik. Som en slags argument for, at værket er en sagligt-videnskabelig og ikke en panegyrisk lovsang af den moderne digtning, nævner Friedrich f.eks. i indledningen, at »han føler sig mere hjemme hos Goethe end hos Gottfried Benn.« Karakteristisk er det, at selv om Friedrich ofte benytter sig af en køligt-distanceret terminologi, der minder om Ortega y Gasséts omtale af digtet som »en ting «, og hvor der f.eks. tales om digtet som »et mønster«, »et fletværk« og »et springbræt«, så afløses denne maskinelt-tingslige metaforik gang på gang af udtryk med korrelation til en okkult-magisk sfære, såsom »stråler«, »sving- 
ning « og »hemmelighedsfuld zone.« Hvor digtet for Ortega y Gassét kun var en død, formålsløs ting, så er det for Friedrich en slags ekstatisk kraftcentrum. I dette citat, der herefter vil blive diskuteret, kommer dette klart til udtryk:

»Digtet vil være et mønster, der er nok i sig selv, strålende ud i mange retninger hvad betydning angår, bestående af et fletværk af spændinger af absolutte kræfter, der på suggestiv måde virker ind på førrationelle bevidsthedslag... Den dissonantiske spænding i det moderne digt viser sig også i en anden henseende. Træk af arkaisk, mytisk, okkult herkomst kontrasteres med skarp intellektualitet, enkel udtryksform med det komplicerede i udtrykket, sproglig færdigstøbthed med indholdsmæssig uafklarethed, nøjagtighed med absurditet, motivisk ubetydelighed med det hektiske udtryk ... Når det moderne digt berører virkelige forhold... så behandler det dem ikke beskrivende eller omfatter dem med den fortrolige erkendelses og følelses varme, men fører dem over i det ufortrolige, fremmedgør dem, deformerer dem. Digtet vil ikke holde sig til det afmålte, man almindeligvis kalder virkeligheden, men det kan i sig selv have optaget rester af den i sig som et springbræt for sin egen frihed. Virkeligheden er frigjort fra den rumlige, tidslige, saglige og sjælelige orden og unddraget den skelnen, som er nødvendig for en normal orientering i verden...: mellem skønt og hæsligt, nært og fjernt, lys og skygge, mellem smerte og glæde, mellem jord og himmel. $«^{41}$

Går vi frem i tiden til 1983 og konsulterer den danske modernistiske bannerfører Torben Brostrøm, er valoriseringen af modernismen anderledes positiv. I Brostrøms talrige værker, af hvilke Modernisme for og nu er et af de seneste, er den modernistiske lyrik hverken nogen y Gassét'sk død, formålsløs ting eller noget Friedrich'sk magisk energicenter, men noget, der tilkendes aktiv, målrettet tankevirksomhed og handling. Brostrøm bruger begreber som »omstøbningsprocesser «, »kosmos«, »orden « og »forslag til virkelighed «:

»I mere end hundrede år har digtningen arbejdet fra steder i bevidstheden, hvor værdier nedbrydes og skabes. Det har konsekvenser for det kunstneriske udtryk, der både bærer og udfører omstøbningsprocesser. Det har sin pris. Sproget har da ikke de etablerede sammenhænge at henholde sig til eller gengive, det må hver gang gøre sig forståeligt forfra. ... Det kan det naturligvis ikke i absolut forstand. Derfor finder digterens sprog sine tilknytningspunkter på de mindst populære og overrendte veje og bliver måske selv svært tilgængeligt. Modernismens digtning befinder sig i kaos med en bevidsthed om kosmos. Derfor ser man tit, hvordan den unders $\emptyset$ ger og understreger det splittede liv eller er optaget af 
en anderledes orden end den herskende uden derfor at kende dette anderledes.... Det særlige ved modernismen er, at digterværket vil bevise sin virkelighed gennem skriften/kunsten selv. Brugsdigtning, realistisk litteratur refererer til virkeligheden. Anderledes er det, når værket er sit eget forslag til virkelighed. $\ll^{42}$

Ud fra de tre ovenstående æstetisk-eksistentielle bestemmelser af 'lyrisk modernisme', er det muligt at uddestillere fire centrale karakteristika. ${ }^{43}$ Det drejer sig for det første om den komplekse, disharmoniske og splittede bevidsthed. For det andet om oppositionen. For det tredje om protesten imod enhver form for normalsprog og almene kommunikationsmønstre, samt skabelsen af et nyt, ubesmittet poetisk sprog. Og endelig for det fjerde om et alternativ til den eksisterende tilstand i form af en epifani eller en visionær særverden.

\section{a) Den komplekse, disharmoniske og splittede lyriske bevidsthed.}

Overalt i poetik og poesi i de sidste 200 år tematiseres forestillingen om en strid eller diskontinuitet mellem krop og bevidsthed. Denne spænding mellem drøm og realitetssans, følelse og fornuft, længsler og internaliseret samfundsmæssig tvang eller biologi og etik er selve motoren i den modernistiske skabelsesproces. Den klare, enkle, rolige, stabile, tilfredse bevidsthed eksisterer stort set ikke i den modernistiske digtning, idet den har fået stemplet banalitetens mærke på sig. Hos y Gassét tales der om det moderne digts »dunkle verdener «, mens vi hos Friedrich får et helt katalog af eksempler på »dissonantisk spænding «, nemlig at »træk af arkaisk, mytisk, okkult herkomst kontrasteres med skarp intellektualitet, enkel udtryksform med det komplicerede i udtrykket, sproglig færdighed med indholdsmæssig uafklarethed, nøjagtighed med absurditet, motivisk ubetydelighed med det hektiske udtryk.« Endelig taler Brostrøm om, at »digtningen arbejder fra steder i bevidstheden, hvor værdier nedbrydes og skabes«, om at »modernismens digtning befinder sig i kaos«, og at »den undersøger og understreger det splittede liv.«

Går vi til digterne selv, er det ikke blot i den modernistiske poesis grundstemning og strukturelle udformning, at vi kan se tendensen mod iscenesættelen af en kompleks, dissonantisk og splittet bevidsthed, men også i en mængde eksplicitte poesiprogrammatiske udsagn.

Blandt de berømte eksempler fra verdenslitteraturen er Rimbauds Lettres du voyant (1871), hvor det siges, at måden hvorpå digteren »kan nå frem til det ukendte «, d.v.s. få sine poetiske visioner, er ved at »skabe lange, grænseløse, fornuftstyrede forvirringer af alle sanser.« Eller mere radikalt udtrykt: 
»Det gælder om at skaffe sig en misdannet sjæl, ligesom manden der indpoder vorter i sit ansigt. « ${ }^{44}$ En senere myteomspunden formulering, der har haft effekt på et utal af poeter er Nietzsches: »Man må have kaos i sig for at kunne føde en dansende stjerne« (1891).

I dansk lyrik er eksemplerne tilsvarende talrige. Man kan nævne Johannes V. Jensens »Interferens «-poetik fra Digte 1906, hvor »mit Hjærtes hede Spænding holder mig Vaagen, / men jeg overvejer med kølig Hu«, »længe tænker jeg med iskold Ro / på den flammende Utaalmodighed, der er min Skæbne«, og »naar Forestillingen om Verdens topmaalte Under mødes med Forestillingen om alle Tings Endelighed / da lever jeg.« Man kan tage Tom Kristensens Nietzsche-inspirerede ekspressionistiske poetik fra 1920erne med $»$ Er en Fribytter ikke en Skaber, / der kæntrer med sjæleblank Ro / for atter at støbe sig Syner / med lysere farverig Tro / for atter med voldsomme Hænder / af skabende Evne krummet / at slynge sin indre Verden / med dens Flammehjul ud i Rummet? «Eller andre berømte citater fra den samme digter: »I Chaos jeg løfter min Bøsse / mod Skønhedens Stjerne og sigter«, og »Asiatisk i Vælde er Angsten. / Den er modnet med umodne Aar. / Og jeg føler den dagligt i Hjærtet / som om Fastlande dagligt forgaar. // Men min angst maa forløses i Længsel / og i Syner af Rædsel og Nød. / Jeg har længtes mod Skibskatastrofer / og mod Hærværk og pludselig Død. «5 I tressernes konfrontationsmodernistiske poetik optræder der hos Rifbjerg en mængde formuleringer, der handler om den disharmoniske psykiske tilstand som ophav til poesien, såsom »fantasiens hungerrum «, »sprængte bevidsthedshinder «, »bevidsthedslykken et turboapparat / før tiden, vingeflugt og jubelsmerte«, »saglighed, salighed « og »opdykket jernfortid / guflende i det ukendte mareridt, henter længst / udsvedte drømme, gumlende / host af fortid, nattevåde / opløste sengetæpper og smagen / af jern i munden mens feberen / er højest muddermaskinefølelse af uafrysteligt konsistensfedt. $\ll^{46} \mathrm{Og}$ vi kan gå til dansk 80er-digtning hos Søren Ulrik Thomsen og finde analoge beskrivelser: »Jeg kan ikke sove for mit sprog blir ved og ved / som et endeløst godstog lastet med svaler og rust «, og »jeg er træt af min egen fors $\varnothing$ lvede tunges / uhyggeligt skønne sange, / jeg længes efter en større, / næsten uhørlig musik «, og »en enorm og sælsom bevidstløshed / famler efter det sted, / hvor sjælen er loddet fast til kødet. $\ll^{47}$

Et andet udslag af disharmoni-fænomenet er den såkaldte »depersonalisering « i digtningen. Med dette fænomen sker der en underminering af ideen om en stabil, centralperspektivisk og moralsk forankret digtning. Et lyrisk jeg er en position i et tekstlandskab. Talrige digtere fra Poe over de franske symbolister til engelske Eliot og danske la Cour har bekendtgjort, at et af poesiens vigtigste mål er at »udslette jeget i digtet«, hvilket vil sige, at der i digtet sker en total distancering fra den skrivende privatperson. Baudelaire taler om, at »hjertets anlæg for følelse ikke er gunstigt for det digteriske arbejde $\ll,{ }^{48} \mathrm{og}$ 
Rimbaud fremfører i Lettres du voyant, at »min overlegenhed består i, at jeg ikke har noget hjerte. ${ }^{49}$ Hjertet er her en metafor for privat lykke og lidelse og borgerlig identitet og adfærd, og kritikken er rettet imod samtidens romantiske epigon-digtning med dens private bekendelser, sentimentalitet og refleksioner over digterens skæbne. Mest radikalt udformes depersonaliseringsideen hos Eliot, for hvem der nærmest hersker en omvendt proportionalitet mellem et kunstværks referencer til en privat skæbne og dets kunstneriske kvalitet:

»Jo mere fuldendt kunstneren er, des dybere vil adskillelsen i ham være mellem mennesket som lider og bevidstheden, som skaber, og des mere fuldstændigt vil bevidstheden fordøje og forvandle de lidenskaber, som er dens stof. $\ll^{50}$

Et eksempel på en annektion af Eliots idé om inkommensurabilitet mellem privat udsagn og kunst er Pia Tafdrups poetik Over vandet går jeg fra 1991. Hver tids lyriske modernisme har sit kunstneriske fjendebillede, og det private udtryk har næppe i dansk litteratur været mere ilde set, end blandt de tidlige firseres digtere, da de i forbindelse med deres gennembrud så sig selv i voldsom opposition til den såkaldte bekendelseslitteratur. Tafdrup skriver:

»Der kan aldrig blive tale om kunst, med mindre det private stof er bearbejdet og selv de mørkeste begivenheder eller mest rystende oplevelser transformeret til lys. Digtet har ikke egenværdi, førend jeg forlader det, hvilket betyder, at jeg ikke må være til stede som privatperson. Det partielle må ikke kvæle det universelle. $\ll^{51}$

Depersonaliserings-tanken har også andre mål end at adskille kunst fra ikkekunst. Når Pia Tafdrup i 1991 siger, at »min tematik kan blot ses som en del af en fælles stoflig ejendom $\ll, 52$ forbinder hendes formulering sig med en fortolkning af »depersonaliseringen «, der for alvor er slået an siden mellemkrigstiden. Man finder fra denne periode Eliots forestilling om »an objective correlative $\ll^{53}$ og Bretons surrealistiske manifester. Og man har Jungs »Psychology and Literature « (1930), hvor det fremføres, at digteren har særlige forudsætninger for at tolke det kollektive ubevidste, det arketypiske. Begreberne refererer hos Jung til en psykisk dybdestruktur, som er nedarvet gennem generationer, og som indeholder en viden ud over, hvad den enkelte kan erhverve gennem egne erfaringer. Digteren skal derfor eliminere ethvert privat element fra sin digtning. Først da kan han udtrykke den dybe kollektive visdom.

Samlende kan vi altså se, at den modernistiske lyriks poetik som en grundantagelse har, at der i digtningen langtfra foregår nogen let overførsel af et personligt stof eller nogle ideer i en række kunstneriske former, som man fore- 
stiller sig i klassisk poetik. Digtet er derimod en 'organisme', der fødes i dybeste smerte, hvad enten digtet er et produkt af en misdannet, splittet, kaotisk sjæl eller en mere kalkuleret depersonalisering, hvor bestemte, private sider af personligheden bortskæres for at få adgang til dybe, psykiske potentialer.

Resulatet er i alle tilfælde, at grundideen om modernistisk digtning tenderer mod en opskrivning af det komplicerede og en nedvurdering af det enkle. Eliots formulering om dette fra »The Metaphycical Poets« (1923) lyder: »Vor civilisation omfatter stor variation og kompleksitet, og denne kompleksitet må, når den indvirker på et raffineret og følsomt temperament, skabe varierede og komplekse resultater. $\aleph^{54}$

Når kritikere har skullet forsvare den modernistiske poesi mod anklagerne om at være »uforståelig « og »underliggjort«, har man fremført, at det i stedet drejer sig om »mulighedsrigdom« eller »frihed for entydig betydning. « Poul Borum eksempelvis har i sin forfatterskole forsvaret et oppositionelt credo med ordlyden: »Digte skal være dybe og klare og enkle. $\aleph^{55}$ At en sådan idé langtfra er slået igennem i Danmark eller nogen andre steder, er dog oplagt, hvis man betragter modernistisk lyrik fra de seneste år. Vi er stadig som på Ortega y Gasséts tid »spærret inde i dunkle verdener« i det modernistiske digt.

\section{b) Oppositionen til det sociale}

Et kernepunkt i den modernistiske poesi som helhed er dens opgør med enhver forestilling om en almen social virkelighed. De tre citater af Ortega y Gassét, Friedrich og Brostrøm, som indledte afsnittet om »Æstetisk-eksistentiel modernismebestemmelse«, lægger alle vægt på dette. Ortega y Gassét taler om en fuldstændig bortvendthed fra sociale sammenhænge, hvor kunstneren i sine værker har brændt »de skibe, som kunne have ført os tilbage til vores vante omgivelser.« Og Mallarmé »afslog at gøre brug af det naturlige materiale«, og han skabte »ting, som ikke forekom i den menneskelige flora og fauna.« Det er vigtigt at være opmærksom på, at y Gassét med »menneskelig« og »naturlig « mener »alment vedtaget«, og at han faktisk har stor veneration til overs for den moderne kunst. Ortega y Gassét betoner, at den modernistiske kunst ikke blot ser sig selv i opposition til en mimetisk poetik, hvor intentionen er at »spejle« en virkelighed, men også til en pragmatisk litteraturforståelse, hvor relationen værk-læser står i centrum.

Hos Hugo Friedrich er påpegningen af den modernistiske kunsts antimimetiske holdning ${ }^{56}$ ikke helt så kategorisk som hos y Gassét. Friedrich siger, at »når det moderne digt berører virkelige forhold...så behandler det dem ikke beskrivende eller omfatter dem med den fortrolige erkendelses og følelses varme, men fører dem over i det ufortrolige, fremmedgør dem, deformerer dem. « Og han anfører videre, at »digtet vil ikke holde sig til det afmålte, man 
almindeligvis kalder virkeligheden, men det kan i sig selv have optaget rester af den i sig som et springbræt for sin egen frihed.« I Friedrichs terminologi med »fremmedgøre «, »deformere « og »springbræt for sin egen frihed « er der i højere grad tale om en forvrænget anvendelse af virkelighedseffekter som udtryk for psykiske forhold. Et nøglebegreb for Friedrich er »sansemæssig irrealitet «, hvorved han forstår, at »det deformerede virkelighedsstof kommer til udtryk i ordgrupper, hvor de enkelte elementer har sansemæssig kvalitet«, men at disse grupper forener »det, der sagligt set er uforeneligt på en så abnorm måde, at der af sansekvaliteterne opstår en dannelse af irreal karakter. $\ll^{57}$

Endelig finder vi hos Brostrøm i 1983 den samme afvisning af enhver didaktik i den modernistiske poesi. Brostrøm håndhæver, som de danske 80erdigtere Strunge, Jac, Tafdrup og Thomsen, et knivskarpt polemisk skel mellem 70er- og 80er-lyrik: »Det særlige ved modernismen er, at digterværket vil bevise sin virkelighed gennem skriften/kunsten selv. Brugsdigtning, realistisk litteratur refererer til virkeligheden. Anderledes er det, når værket er sit eget forslag til virkelighed. « Når det netop ved 80ernes indgang er påtrængende at påpege, at de i disse år debuterende forfattere skriver traditionsbevidst modernistisk poesi, er det selvfølgelig, fordi den sofistikerede, formbevidste del af digtningen i et tiår har stået i skyggen af en mere handlings- og erfaringsrelateret digtning. Hos de tidlige 80er-digtere er det umådelig vigtigt at undsige enhver form for forbindelse med samfundsmæssige institutioner, samt at tage afstand fra, at det personlige kan oversættes til det samfundmæssige via det politiske, som man finder det i en del af 70ernes brugslitteratur.

Man bemærker for både y Gasséts, Friedrichs og Brostrøms vedkommende et særligt træk ved diskursen omkring lyrisk modernisme, nemlig den polemiske måde, hvorpå man omgås problemet »virkeligheden. «Ingen ved, hvad »virkeligheden « er. Og man er ikke det mindste interesseret i at vide det. Når der således tales om »den menneskelige flora og fauna « (y Gassét), »det afmålte, man sædvanligvis kalder virkeligheden« (Friedrich), og at »værket er sit eget forslag til virkelighed « (Brostrøm) er der tale om ren spot over for dem, der $\emptyset$ nsker at definere en fast, almen virkelighed, hvad enten de kalder sig realister, positivister eller andet. Den lyriske modernismes 'virkeligheds'ironisering er kort sagt en omvending af den problemstilling, som Stounbjerg med Frankfurterskolen i ryggen fremlægger, nemlig billedet af den moderne digter som et passivt objekt for en destruktiv modernitet. Frem for at forstå digteren ud fra en sociologisk orienteret æstetik med kategorier som fremmedgørelse, chokoplevelse, subversiv længsel og instabilitetens æstetik, kan man opfatte ham som et subjekt, der ytrer sig med autoritet fra sit frivillige eksil.

I hvert fald rummer den modernistiske tradition mangfoldige udsagn om, hvordan digteren med myndighed vælger at tage afstand fra og omskabe en alment accepteret virkelighed i digtningen. Eksempler er Nietzsches »Kunst- 
neren tåler ikke virkelighed «, eller Wallace Stevens om at »kunstneren må tage afstand fra virkeligheden, hvilket han gør ved at placere den i sin fantasi.« Og man har naturligvis Rimbaud som prototypen på en poet, der baserer hele sit (korte) forfatterskab på et gennemgribende opgør med enhver form for eksisterende social virkelighed. I Rimbauds poetiske univers er der kun én lov, nemlig de hvirvlende feberhede drømme eller, som Friedrich kalder det, »den diktatoriske fantasi.« Den 17-årige digters berømte digt, »Le Bateau Ivre« (1871) er en af mange uhyre bastante tilkendegivelser af, at opgøret med civilisationen er totalt (»ligeglad med enhver besætning «). Der er intet i den utilitaristiske og småtskårne sociale orden (»flamsk hvede eller engelsk bomuld «), der kan tilfredstille længslen efter drømmens landskaber: »Da jeg flød ned af de stille floder, / følte jeg mig ikke længere under bådstagernes førerskab: / skrigende rødhuder havde sikret sig dem til skydeskiver, / naglet dem nøgne til malede stager. // Jeg var ligeglad med enhver besætning, / der transporterede flamsk hvede eller engelsk bomuld. / Da det var sket med deres og mine stageres skrig, / lod strømmen mig flyde, hvorhen jeg ville. $«^{58}$

Afskrivningen af en almen virkelighed omfatter dog ikke kun samfundet $i$ materiel og institutionel forstand. Helt centralt er også den modernistiske lyriks antiideologiske karakter. Når Friedrich siger, at det modernistiske digt er »frigjort fra den rumlige, tidslige, saglige og sjælelige orden, « understreges det, at ingen vante forestillinger gives adgang til digtningen. I modernistisk poetik er der teoretiseret meget over denne intethedstilstand, dette magiske psykiske tomrum frigjort fra alle tankesystemers forstyrrende indgriben, hvori poesien fødes. Eksempler er Gottfried Benns centrale begreb »intethedens formkrævende magt « fra »Lyrikkens problemer« (1951) og Thorkild Bjørnvigs refleksioner fra »Intethed og form« (1960). Hos Bjørnvig er udgangspunktet et citat af Yeats: »Hvad Part i Verden kan Kunstneren, som / er vågnet fra den fælles Drøm, have andet / end Udsvævelse og Fortvivlelse? « ${ }^{59}$ Svaret på det stillede spørgsmål er: den kunstneriske skabelsesproces. Først efter at have afskrevet ethvert bekræftende forhold til den eksisterende omverden og overgivet sig til ensomheden er vejen banet for den originale kunstneriske frembringelse. »»Ødelæggelsen blev til min Beatrice«, og »efter at have fundet intetheden fandt jeg skønheden«, sagde Mallarmé. « ${ }^{60}$ Også i ny dansk poesi og poetik genfinder man »intetheds«-temaet, som f.eks. i Pia Tafdrups Over vandet går jeg (1991), hvor begrebet »intetfang «, hentet fra filosoffen Ludvig Feilberg, lanceres: »Der er perioder, hvor jeg synker ned i intetfang, forlader det konkrete og giver slip i en tranceagtig og fraværende tilstand .... I de mest nærværende øjeblikke, de der består af fang, sættes alle sanser ind på en gang i en totaloplevelse, hvor der næsten sker en kortslutning mellem sanserne. ${ }^{61}$

Når den modernistiske poesis afvisning af den samfundsmæssige virkelighed er blevet diskuteret, er der endnu en side ved problemstillingen, der bør 
berøres, nemlig konflikten mellem den udvalgte kunstner og den uforstående eller direkte fjendligt indstillede hob. Det er denne spaltning mellem poet og publikum, som Ortega y Gassét aktualiserer, når han taler om »at det at beskæftige sig med kunstværkets menneskelige indhold er uforeneligt med den æstetiske nydelse. «Den modernistiske kunst tages kun til hjertet af de få særligt kvalificerede, siger y Gassét. Hos Baudelaire er poesien forbundet med »den aristokratiske fornøjelse at mishage«, og i Fleurs du Mal's indledende tiltale af hans »Hypocrite lecteur « bliver der i den digteriske udsigelsessituation kun hån og ironi til overs for en klassisk pragmatisk kunstforståelses idé om, at kunsten bør »gavne og fornøje« (»utile dulce«).

Går vi til dansk digtning, er der ligeledes talrige eksempler på den modernistiske poesies aristokratiske distanceren sig fra en rindalistisk indstillet $p \varnothing-$ bel. Vi kan tage Bjørn Poulsens »Elfenbenstårnet « (1949) eller Gustava Brandts credo fra hans poetik Hvad angår poesi (1982): »Kunstværker er for hvemsom-helst, men ikke for alle-og-enhver.« Eller vi kan gå til 60ernes konfrontationsmodernisme og finde poetikagtige slogans som Ørnsbos »Digtet er en kniv læseren træder på« (1960) og Rifbjergs »Jeg er ikke for fastholdere « (1960). Endelig kan man betragte den danske 80er-digtning med Søren Ulrik Thomsen og finde følgende klassisk modernistiske melding: »Til jer der anklager poesien for eksklusivitet / og råber: Ud med sproget! - / det er verden der er et elfenbenstårn; / hvert digt en ansøgning om at få adgang «(1987).

Konkluderende ser man altså, at afvisningen af den forhåndenværende sociale virkelighed er et kernepunkt i modernistisk poesi, hvad enten den ytrer sig som antiideologisk eller antipragmatisk poetik.

\section{c) Skabelsen af et nyt, renset, poetisk sprog}

»Små lyriske ting, der ikke findes i den menneskelige verden«, og »et mønster, der er sig selv nok «, lyder nogle af Ortega y Gasséts og Hugo Friedrichs karakteristikker af den moderne lyrik. Tilsvarende taler Brostrøm om, at »det særlige ved modernismen er, at digterværket vil bevise sin virkelighed igennem kunsten/skriften. « Hermed er vi inde på endnu et essentielt træk ved modernismens poetik, nemlig at den ved sin hævdelse af digtets autonomi og af sprogets materialitet lægger afstand til en romantisk og realistisk/naturalistisk poetiks forestilling om, at sproget er som et transparent medium, gennem hvilket en subjektiv eller objektiv virkelighed kan overføres fra forfatter til læser. Berømt er i denne sammenhæng y Gasséts »vindue-have «-analogi fra Menneskets fordrivelse fra kunsten. Ideen er, at vi, d.v.s. kunstpublikummet, i den klassiske og romantiske kunst, når man kigger gennem en rude og ud på en have, kun ser haven bagved, d.v.s kunstværkets motiv eller indhold. I den moderne, »upopulære« kunst forholder det sig helt anderledes. Her ser vi kun ru- 
den, hvad enten det er maleriets linier og farver eller litteraturens sprog. Og selv om nykritikken har satset på at nedbryde forestillingen om, at modernistisk kunst er ren form ved at hævde, at digtet udgør en ubrydelig enhed af form og indhold, er det alligevel et gennemgående træk i næsten al modernisme, at det digteriske sprog forstås som et materiale eller en værdi i sig selv.

En række citater af den modernistiske lyriks kirkefædre har været brugt utallige gange i diskussionen af moderne digtnings koncentration om sproget som medium. Fælles for hele den franske eksperimenterende digtning fra 1800-tallet med dens meget forskellige repræsentanter Baudelaire, Rimbaud, Verlaine og Mallarmé, som senere er blevet benævnt symbolisterne, er den opfattelse af digtet, som noget der i højere grad skal gribes klangligt-suggestivt end egentlig begribes. Digtet har fralagt sig enhver meddelende funktion og er i stedet en uafhængig organisme opbygget af musikalske kraftfelter.

Rimbauds kompromisløse forestillingsverden omfatter bl.a. ideen om en »Ordets Alkymi«: »Jeg beregnede form og bevægelse for enhver konsonant og bildte mig ind ved hjælp af sprogets medfødte rytme at finde et poetisk urord, som før eller senere kunne blive tilgængeligt for alle sind.« Og i en anden sentens: »Jeg opfandt vokalernes farver! A sort, E hvid, I rød, O blå, U grøn. « ${ }^{62}$ Der er ingen grænser for den magi, som det kunstneriske sprog tillægges hos Rimbaud. Målet er at omstyrte verden med et helt »nyt universelt sprog.«

Ikke så forskellig fra, men med udgangspunkt i et anderledes køligt, kalkulerende syn på den digteriske akt, er Mallarmés syn på det poetiske sprog. To forhold er her vigtige. For det første tillægger Mallarmé sproget voldsomme mystisk prægede kræfter og digtet en placering over alt andet i universet. Han lægger vægt på, at poesiens sprog skal være »dunkelt« for at adskille sig fra dagliglivets entydige, referentielle sprog og opererer med et suggestionsbegreb. Hermed menes, at digtet virker med en magisk kraft på læseren, der skyldes det særlige ved det digteriske sprog, nemlig at det kun må antyde og aldrig benævne noget. På denne måde gives læseren adgang til »intethedens mystik.« For det andet betoner Mallarmé illusionsløst, at »digtningen arbejder med ord og ikke ideer «, som en legendarisk formulering lyder. Mallarmés yndlingsmetafor for det digteriske arbejde er hentet fra den positivistiske videnskab: han arbejder i sit »laboratorium « med »sætningens geometri. « ${ }^{63}$

Både Rimbauds og Mallarmés version af en kraftig opvurdering af poesiens særlige sproglige karakter har haft stor tilslutning i det 20. århundrede. Rimbauds holdning videreudvikles i surrealisternes opfattelse af et frit, utæmmet underbevidst styret sprog som et revolutionært potentiale. Mallarmés genfindes derimod i de angelsaksiske imagisters nøgterne søgen efter minimalistiske sproglige udtryk, de tyske Der Sturm-digteres struktur- og grafisk konstruerede digte, og i Skandinavien i 1950ernes svenske og 1960ernes danske konkretistiske poesi. Parallelt med udviklingen af Mallarmé-linien inden for 
modernsitisk lyrik kan man inden for litteraturvidenskaben iagttage en »sproglig vending «, hvor digtningen i tiltagende grad beskrives som et »underliggjort sprog « skabt med bestemte »greb «, eller som en specifik anvendelse af en række retoriske figurer. ${ }^{64}$ Adskillige steder i det 20. århundredes poesi ser man desuden, at Mallarmé- og Rimbaud-retningerne mødes i forfatterskaber, hvor poesi på én gang opfattes som en suggestiv okkult kraft og som en perfektionistisk kontrolleret form. Det gælder f.eks. den sene Eliots Four Quartets (1943): »Words move, music moves / Only in time; but that which is only living / Can only die. / Word, after speech, reach / Into the silence. Only by the form, the pattern, / Can words or music reach / The stillness, as a Chinese jar still / Moves perpetually in its stillness. $\ll^{65}$

I dansk lyriktradition finder vi beslægtede symbolistiske, mallarméske suggestions-ideer i Sophus Claussens forståelse af $»$ verset som organ. $\aleph^{66} \mathrm{Er}$ den symbolistiske digtnings vægtning af poesiens magiske, musiske kræfter et vigende fænomen i det 20. århundrede, som Bo Hakon Jørgensen påpeger det $\mathrm{i}$ Symbolismen - eller jegets orfiske forklaring (1993), så sker der til gengæld en voldsom »sproglig vending « inden for lyrikken i retning af, at det enkelte ord som sprogligt materiale på den hvide side bliver sat i focus. Man kunne tale om et paradigmeskift fra en $\emptyset$ rets poesi, hvor verset som hos Claussen er »et organ« til en øjets poesi som hos Friedrich og andre, hvor digtet beskrives som »et mønster.« Vi kan notere dette skift, hvis vi ser på den nyorientering, som avantgardebevægelsernes poesi igangsætter i opfattelsen af digtet som en sproglig konstruktion. I Danmark med dets »umådelige mådehold « er det dog hovedsagelig hos de ganske få oversete avantgardedigtere fra 1920erne såsom Bønnelycke, Momberg og Broby-Johansen, at dette kommer til udtryk.

Først i 1960ernes danske konkretistiske digtning eller 3.-fase-modernisme er den sproglige vending inden for dansk modernistisk digtning for alvor slået igennem. Kunstværket skal nu vere frem for at henvise, og at digte består af sprog og intet andet. Hans-Jørgen Nielsen proklamererer i sin generationsantologi Eksempler (1968), at poesien ikke er erkendelse, for noget sådant »kræver at verden a priori har en dybere natur, digtet eller digteren kan få indblik i.«I stedet får poesien status som eksempel. Digte er »noget man gør med sproget. $\ll^{67}$ Vagn Steen skriver i Laesninger (1969), at »det drejer sig ikke om, hvad digteren oplevede, men om at læseren oplever. $\aleph^{68} \mathrm{Og}$ Højholt bekendtgjorde i Cézannes metode (1967), at »digtet ikke er nogen udlægning eller fremstilling. Det er en ting. Der er ikke noget foran eller bagved «, samt at »hvis en lyriker af sit digt kræver, at det skal være et eksempel på sprog, kan han ikke samtidig forlange af det, at det skal være bærer af hans personlighed i form af udsagn, bekendelse, anatema etc. $\ll^{69} \mathrm{I}$ de sene tresseres og tidlige halvfjerdseres danske digtning får den sproglige orientering ofte en politisk dimension. Skabelsen af det nye poetiske sprog begrundes med, at det at ac- 
ceptere det herskende sprog er at acceptere den herskende samfundsorden. Det er simpelthen påkrævet at tage springet over i et ny sprog. ${ }^{70}$

I dansk 1980er-digtning er der talrige eksempler på l'art pour l'art-holdningen, hvor det betones, at der ingen vej går fra kunstværket og ud i verden. Specielt markerer digterne Søren Ulrik Thomsen, Niels Frank og Lars Bukdahl sig med minimalistiske, konkretistiske poetikker. Søren Ulrik Thomsens poetik Mit lys brander. Omrids af en ny poetik beskæftiger sig således med det referencefri kunstværk, hvor man sætter »subjekt-objekt forholdet mellem værket og publikum på programmet. $\ll^{71}$ Digtene $»$ har intet at udbrede og intet at udbrede sig om ${ }^{72}$ og $\gg$ handler ikke om andet, end at den, der sidder og læser dem lige nu, sidder og læser dem lige nu. « ${ }^{73}$

Thomsens syn på kunsten som noget autonomt og det digteriske sprog som noget, der markerer sin fundamentale forskellighed i forhold til andet sprog, er, som vi har set, et helt gennemgående træk i den modernistiske lyrik. At det ikke kan lade sig gøre at skabe den »absolute Wortkunst«, der undgår enhver form for befængthed fra dagligliv og almindeligt sprog er selvfølgelig indiskutabelt. Men at den fortsatte jagt på den i-sig-selv-hvilende kunst og det helt originale sproglige udtryk er en hoveddrivkraft i den modernistiske poesis udvikling, er lige så sikkert.

\section{d) Den alternative tilstand som epifani eller visionaer sarverden}

Ser vi endelig på det fjerde modernistiske grundtræk har vi - i modsætning til de tre foregående - at gøre med et træk, der kan være svært at sætte på en fællesnævner. Når vi taler om en frigørelse fra og et alternativ til den eksisterende tilstand, kan dette antage mindst fire forskellige former, nemlig en religiøs eller politisk præget utopi, en visionær sanselig drømmeverden, et epifanisk oplyst nu eller en konkret fysisk-psykisk lykketilstand.

Lad os for sidste gang konsultere de tre modernismeteoretikere, der indledte dette afsnit. Ortega y Gassét tilkender kun i ringe grad den moderne poesi nogen form for konstruktiv forandrende kraft, ud over at den kan give »instinktaristokratiet«, d.v.s. de kunstneriske feinsmeckere, der forstår den moderne kunst, en æstetisk oplevelse af »indespærring i dunkle verdener.«

Anderledes for Friedrich. Hos ham skænker det moderne digt os ikke bare nydelse og nervechok, men kan også udtrykke emancipatoriske potentialer. Når digtet kan være et »springbræt for sin egen frihed « og er »frigjort fra den rumlige, tidslige, saglige og sjælelige orden« etc., er det for at pege på, at det modernistiske digt artikulerer drømme og indsigter, der er forvist fra den samfundsmæssige midte. Geografiske (»nært og fjernt«), religiøse (»jord og him- 
mel«), æstetiske (»skønt og hæsligt«) normer sætter grænser i vort liv. Disse normer sprænger det modernistiske digt.

I Friedrichs modernismetænkning er begrebet »tom transcendens « af største betydning. Med dette menes, at »opstigningens punkt «i digtet »ikke blot er fjernt, men tomt, en indholdsløs idealitet. Den er en ren og skær spændingspol, hyperbolisk tilstræbt, men ikke til at betræde. ${ }^{74}$ Når Friedrich, specielt med udgangspunkt i Baudelaires stræben mod »azuren« og Rimbauds søgen efter »det ukendte«, generaliserer termen »tom transcendens « til at gælde for al modernistisk poesi, skal det dog tages med forbehold. Til eksempel er begrebet kun i ringe grad dækkende for den del af modernismen som R. N. Maier i Paradies der Weltlosigkeit (1964) har betegnet som »reine Abstraktion«, d.v.s. den konkretistisk-minimalistisk orienterede del af digtningen.

I Brostrøms vurdering af modernismens visionære karakter er optimismen langt større. Modernistisk lyrik er for Brostrøm ikke bare i stand til gennemskue det falske og forlorne ved den moderne verden, men indeholder også en klippefast tro på en alternativ virkelighed. Digtningen færdes »på de mindst populære og overrendte veje«, og den er »optaget af en anderledes orden end den herskende uden derfor at kende dette anderledes.«Og så med Modernisme - før og nu's mest slagkraftige formulering: »Modernismens digtning befinder sig i kaos med en bevidsthed om kosmos.«

At opremse de mange eksempler fra de sidste 100 års lyrik på forestillinger om digtningen som epifanisk eller utopisk er ganske uoverskueligt. Blandt de mest prægnante danske formuleringer af denne dimension inden for modernistisk lyrik kan nævnes Thorkild Bjørnvigs fra »Moderniteten som holdning «: »Moderne kunst er i sine stærkeste og reneste manifestationer et sakralt provisorium, udtryk for indsigter og erfaringer, som ellers er blevet hjemløse og nægtet realitet i verden, som den er i dag. $\ll^{75}$

Bo Hakon Jørgensen har karakteriseret den symbolistiske digtning som en »litterær/mytologisk perspektivering af et privat jeg. « $^{76} \mathrm{I}$ dansk sammenhæng passer dette godt på Sophus Claussens digtning, hvor modsætningen mellem på den ene side en materialistisk, borgerlig nyttemoral og frihedslængslen, og på den anden fantasien, erotikken og kunsten, transformeres til og bearbejdes $i$ en mytologisk sammenhæng eller et eventyrunivers, som man f.eks. ser det i digte som »Mennesket «, »Livets Kermesse« og »Imperia.« Hos Tom Kristensen, skabes der derimod alternativer til den borgerlige kultur gennem gestaltningen af vilde visionære særverdener, hvor hedonisme og skønhedsdyrkelse udtrykkes i farverige proletariske og eksotiske tableauer. Hos tredivernes Gustaf Munch-Petersen gælder det den surrealistisk inspirerede utopi om »det underste land « (1933) og hos den unge Bjørnvig i Heretica-tidens adventsstemning f.eks. i visionen om »Soria Moria, landet som aldrig var til« (1947). 
I tressernes konfrontationsdigtning er der som følge af påvirkning fra Brostrøms tese om den »forudsætningsløse omverdenserkendelse ${ }^{77}$ nok blevet lagt lovlig stor vægt på digtenes orientering mod et »konkret udsnit af omverdenen. De mest banebrydende tekster fra perioden, såsom Rifbjergs digte fra Konfrontation (1960) »Jern«, »Frihavnen«, »Refshaleøen« og »Middelaldermorgen«, og Camouflage (1961) samt Ørnsbos Digte (1960) og Myter (1964) handler rent faktisk om fantasiens, drifternes og kunstens primat over enhver form for fornuft, norm eller objektiv virkelighedstilegnelse.

Endelig er der næppe tvivl om, at den mest visionært orienterede periode i det 20. århundredes danske lyriske modernisme ligger i 1980erne. Det vrimler i denne periode med poetikskrifter, hvor alternative tilstande i forhold til det bestående er et hovedpunkt. Det kan dreje sig om klassisk symbolistisk-modernistisk orienterede oplevelsesstrategier, som i Tafdrups Over vandet går jeg, hvor nedsynkningen i »intetfang « synes at have åbnet for en vifte af poetiske visioner. En baudelairesk korrespondance-oplevelse med »kortslutning af alle sanser « antydes flere steder hos Tafdrup, men også beskrivelser af mystisk prægede, jeg-transcendente erfaringer lanceres: »Jeg vil se, hvad ingen andre ser, afs $\varnothing$ ge nye rum, grænser mellem indre og ydre, subjekt og objekt, endog fremskrive nye rum. $\ll^{78}$ Der er Rimbaud-inspirerede eksempler på den kreative proces som en synsk eller profetisk akt: »Digte er at gribe fremtiden, før den passerer. $\ll^{79} \mathrm{Og}$ der omtales, i relation til poetikkens titel, en ekstasetilstand, der »løfter og åbner, giver mig en følelse af at gå over vandet. $\ll^{80}$

I Søren Ulrik Thomsens Mit lys brcender, finder man en minimalistisk orienteret fokusering på nu-intensiteten som det overordnede mål. Titlen Mit lys brcender peger på en illusionsløs given sig hen til eksistensens grundvilkår: at livet er et afmålt tidsforløb med døden som den altid nærværende baggrund. Den eneste livsværdi er øjeblikke af intens kontakt med en konkret omverden. Eksempler på poetikkens antimetafysiske og nihilistiske credoer lyder: »det evige liv er $n u \ll$ og $» j e g$ er her fordi jeg er her. $\ll^{81}$ Afstanden markeres på denne måde demonstrativt til den klassiske modernisme med dens utopier om en tabt eller en kommende tilstand.

Andre digtere som Bo Green Jensen har ikke modvilje mod at vedkende sig et slægtskab med tidligere tiders modernistiske digtning, hvad angår længslen efter alternative tilstande. I sin poetiklignede tekst »Den stadige blomstring og den tabte epifani« (1985) argumenterer han for, at den visionære længsel er grundoplevelsen i moderne kunst. Det sker suggestivt med en tour de force gennem de sidste 200 års vestlige civilisations symbolik for det utopiske fra romantikernes »lys « og symbolisternes »krystaller«, »prismer « og »tårne« til Freuds »oceaniske eksistens $«$ og Eliots »tidløse øjeblikke«: 
»Der fokuseres på absolut lys og absolut mørke med en undertiden vild, flængende skønhed. Romantikken kroner epifanierne - de tidløse øjeblikke af indsigt og forklarelse, af oceanisk eksistens i den enkeltes liv og søger i skrift at fiksere dem. Digteren er prismet, som kan holde, samle og dele lyset. Hans hus er et krystaltårn, som rækker ud i tiden og op i evigheden. Det står ikke ved verdens kant, men i dens hjerte. $\ll^{82}$

Endelig har man i den nyeste danske digtning en tredje type af utopier. Det drejer sig om ekspansivt og socialt orienterede utopier med tilknytning til ekspressionistisk og surrealistisk æstetik. Strunges Rimbaud-inspirerede poesi er et markant eksempel, men vi finder også i den yngste danske generation en forfægtelse af denne position hos bl.a. Lene Henningsen. Hendes lyrik ligger milevidt fra f.eks. den minimalistiske poesi og metapoesien, som beskrives i Thomsens Mit lys brander. Hun anerkender ikke kunstens isolation i forhold til livet. Hendes En drøm macket dag fra 1994 har undertitlen »telegrammer om liv/digt « - en formulering, der udtrykker trangen til at forene vision og praksis. I et interview i tidsskriftet Ildfisken siger Lene Henningsen:

»For mig hænger drøm og virkelighed sammen, og mine drømme er ikke uden for verden. De skal realiseres ... Man skal leve drømmen. For mig er alle drømme til stede og mulige i livet. Og i alle mennesker. Jeg bliver aldrig træt af verden og af mennesker, fordi jeg ved, at alle muligheder rummes, det er bare at finde dem. $\ll^{83}$

\section{Anvendelsen af den astetisk-eksistentielle modernismebestemmelse}

Efter at have fors $\varnothing \mathrm{gt}$ at specificere de fire centrale træk ved lyrisk modernisme melder spørgsmålet sig naturligvis: Er disse fire træk blot et tilfældigt eksempel på én karakteristik af modernismen? Det naturlige svar vil i første omgang være ja, men det er dog påfaldende, at de fire fremhævede træk hænger sammen med en mere overordnet opfattelse af begrebet lyrisk modernisme. Det drejer sig om forståelsen af modernismen som en særdeles heterogen moderne kunst, hvor modernismen ikke i første række er en modsætning til hverken romantik, naturalisme eller andre tidligere kunstretninger, men derimod en omfattende syntese, fusion og bearbejdning af æstetiske ideer fra den samlede poesihistorie.

I M.H. Abrams The Mirror and the Lamp (1953) foreslås den samlede vestlige æstetiske tradition opdelt i forhold til fire forskellige grundlæggende litteraturkritiske teorier, nemlig »de mimetiske «, »de pragmatiske«, »de eks- 
pressive « og »de objektive.« Med denne opdeling omplanter Abrams Roman Jakobsons teori om de fire sprogfunktioner til kritikhistorien. Den mimetiske litteraturforståelse - fra Platons Staten til Auerbachs og Lukács realismeteorier - vægter relationen værk-omverden. Den pragmatiske - fra Horats Ars Poetica til renæssancens normative poetikker - forbindelsen værk-læser. Den ekspressive - fra Coleridges »imagination«-teori til i dag - relationen digterværk. Mens den objektive litteraturteori - fra Eliots »impersonalism«-teori og nykritikken til i dag - fokuserer på kunstværket i sig selv. Frem for at betragte disse teorier som historiske epoker, som Abrams gør, er det dog oplagt, at de fire syn stadig danner grundlag for vort litteratursyn. Ligegyldigt hvor mange gange i de sidste 200 års litteraturteoretiske diskurs det pragmatiske, det mimetiske eller det ekspressive litteratursyn er blevet erklæret dødt og passé, så lever det i bedste velgående. For hvordan skal vi ellers forklare, at hver eneste ny modernistisk digtergeneration siden sidste århundrede er startet forfra med at diskutere deres digtnings forhold til hver af de fire typer af litteraturteorier?

I denne fremstillings første modernismekarakteristikon - den komplekse, disharmoniske og splittede lyriske bevidsthed - ligger den uafsluttelige diskussion og kritik af en »ekspressivt« orienteret litteraturkonception. I det andet træk - afvisningen af en realistisk gengivet samfundsmæssig virkelighed - det evige opgør med en »mimetisk « orienteret poetik. Ved det tredje karakteristikon - distraktionen i forhold til normalsproget og skabelsen af et nyt, renset, poetisk sprog - placerer vi os derimod midt i de »objektive« litteraturteorier (i Abrams afhandling menes der hermed anskuelsen af litteraturen som en af andre forhold uafhængig størrelse). Og endelig er det fjerde træk - den alternative tilstand som utopi, epifani eller visionær særverden - en åbenlys opposition i forhold til og dialog med en »pragmatisk« litteraturteori, hvor det er oplagt, at det modernistiske digts måde at gribe ind i sin læsers (f.eks. Baudelaires »Hypocrite lecteur - mon semblable, - mon frère! «) tankeverden er af en ganske anden art end den klassisk-horatianske retoriks og pragmatisk orienterede poetiks rationelt begrundede ideer om »at gavne og fornøje.«

Vigtigt er det yderligere at overveje, hvad vi kan bruge det fremanalyserede modernismebegreb til. Den lyriske modernisme bør anskues som en stor, fleksibel, transhistorisk æstetisk-eksistentiel forståelsesramme for poesi og altså ikke som en tidsmæssigt, nationalt eller idémæssigt afgrænset kunstnerisk epoke. Det fleksible ligger i, at der i forhold til de fire ovennævnte modernistiske poetiske dimensioner er megen lyrik, hvor kun en enkelt eller et par af dem er udprægede. Mens f.eks. Stagnelius' og Tom Kristensens digtning i allerhøjeste grad indeholder det første, det andet og det fjerde træk, møder man kun i begrænset udstrækning eksperimentalpoetiske brud med normalsproget og de vante digteriske former. Og mens der i Apollinaires og Vagn Steens 
digtning kun sporadisk er tale om splittelse, radikal omverdenskritik og visionaritet, så er den med hensyn til brud på genrekonventioner og sprængning af sproglige normer banebrydende. Ialt kan modernistisk lyrik opfattes som en slags æstetisk-eksistentielt univers, hvor visse værker er placeret tæt på centrum i dette på grund af, at de på markant vis indeholder alle fire karakteristika, mens andre har en mere perifér position, udfra at de f.eks. kun i svag grad indeholder et enkelt af de fire træk.

Konsekvensen af denne betragtning er, at man ved hjælp af de fire lyriskmodernistiske dimensioner kan nå frem til frugtbar indsigt på to områder. For det første får man en nuanceret normativ målestok til vurdering af mere eller mindre kunstnerisk vellykket lyrik. For det andet bliver vi i stand til at opspore mindre åbenlyse slægtskaber og litteraturhistoriske sammenhænge mellem modernistiske digtværker fra forskellige tidsperioder og nationalsprog.

\section{a) Det normative system}

Der kan være god grund til at opfatte de fire nævnte lyrisk-modernistiske træk som et fundamentalt normativt system i forhold til lyrik. Modernistisk lyrik er ikke - som vi har slået fast et par gange - en strømning blandt andre, men simpelthen lyrikken i vor tid, d.v.s. hele den moderne vestlige kulturs barometer for god og dårlig lyrik. En digtning, der i rigt mål forholder sig til alle de fire dimensioner - den mimetiske, den pragmatiske, den ekspressive og den objektive - er oftest en rig tekst eller sagt med Pounds statement »stor litteratur er simpelt hen sprog ladet med betydning til den yderst mulige grad. $\ll^{84} \mathrm{Og}$ en tekst, der ikke gør det, er i de fleste tilfælde det modsatte, d.v.s. en fattig, overfladisk og kunstnerisk mindre interessant tekst.

En læsning af to korte, danske lyriske tekster fra de seneste år kan tjene som eksempel på. Den første er af Lars Bukdahl fra Skyer på graes fra 1991.

\section{Døden er}

Døden er den blå giraf

der vandrer rundt

på kirkegårdens små,

grusfyldte stier

og skændes med

den grønne giraf,

som er livet

En gang imellem

sker det 
at den gule giraf,

som er den gule giraf

kommer forbi

og forsøger

at stifte fred.

Måske skal digtet forstås som en humoristisk pastiche over eller parodi på et handlingsforløb i tegneseriens, fablens, eventyrets eller mytens univers. Eller måske er det meningen, at et alvorligt stof - døden! - på elegant vis skal detroniseres i dadaismens ånd. Givet er det i hvert tilfælde, at Bukdahl ønsker at demonstrere $\sin »$ stilistiske brillans $«{ }^{85}$ og ekvilibrisme udi paradoksets, stilbruddets og tautologiens forførende forgreninger. Og at digtets idé er at lave nogle sprogspil, hvor der leges med symbolværdier (»den grønne giraf som er livet«) og døde metaforer og mangelen på samme (»den gule giraf som er den gule giraf «). Man kan konstatere, at digtet hviler på en rent »objektiv litteraturforståelse«, d.v.s. alene eksisterer i kraft af sin formsproglige dimension. Med hensyn til de tre andre lyrisk-modernistiske parametre må man derimod sige, at digtet ikke har meget at byde på. Teksten befinder sig i den absolutte periferi i forhold til vor kulturs modernismebegreb. Og den må ud fra det fremlagte ræsonnement karakteriseres som en fattig og kunstnerisk svag tekst.

Anderledes hvis vi ser på en anden tekst af samme længde, og som også i sin titel påstår at handle om døden, nemlig Søren Ulrik Thomsens »Ikke døden« fra City Slang (1981):

\section{Ikke døden}

Døden er ikke veninden kommer aldrig tilbage

fra sin rejse væk fra Metro Nord, væk væk,

døden er ikke sølv og turkis

sejlende bort fra fascinationens opløste krop

døden er ikke at styrte på gaden

blandt dem der bukker sig og dem der haster

døden er

ikke at elske og alt er som det plejer

Man kan glæde sig over den raffinerede brug af ordet »ikke«, over opladningen af betydning igennem gentagelsesstrukturen, over den typografiske effektfuldhed i liniebruddene eller over billedsprogets kombination af konkretion og sansemæssig irrealitet (»sejlende bort fra fascinationens opløste krop«). Men man er dog ikke i tvivl om, at digtet adskiller sig fra Bukdahls, ved at det ikke blot har en retorisk dimension, men også de tre øvrige, vi har nævnt. Den 
eksistentielt-ekspressive dimension i digtet markerer sig som en atmosfære af indre nødvendighed. I »Ikke døden« videregives et jegs yderst komplekse omverdensoplevelse: Ensomhedsfølelsen er viklet ind i forelskelsen, angsten i fascinationen af hæsligheden, tomhedsfølelsen i ekstasen. Også den mimetisk-sociale dimension står centralt i digtet i tematiseringen af den fremmedg $\varnothing$ relse, som det lyriske subjekt oplever i relationen til den moderne storby. Og endelig er den pragmatisk-visionære modernismedimension tydelig i digtets utopi om »at elske«, og om at alt ikke må være »som det plejer.«

Formålet med denne læsning har ikke været på anmeldervis at komme med en nedrakning af Bukdahl og en besyngelse af Thomsen, men at påpege nogle konturer i en litteraturhistorisk valorisering, der allerede er knæsat. De fire dimensioner er dybt forankret i den litterære kritik, som har hersket i Danmark og i resten af den vestlige kultur i generationer. Når Thomsen har indskrevet sig i den danske litteraturhistorie, skyldes det i høj grad, at han - som så mange andre modernistiske danske poeter fra Claussen og Jensen over Sarvig og Bjørnvig til Rifbjerg og Malinowski - har skabt et lyrisk værk, der med stor originalitet og intensitet har bemægtiget sig de fire modernistiske dimensioner.

\section{b) Alternative litteraturhistoriske perspektiver}

I starten af denne artikel blev det beskrevet, hvordan modernismebegrebet, specielt inden for angelsaksisk litteraturforskning, har været snævert knyttet til en litteraturhistorisk periodiseringsbestræbelse. Det er i den forbindelse oplagt, at en del af den historisk og idéhistorisk samt den biografisk orienterede litteraturvidenskab har virket hæmmende i forhold til alternative perspektiver på litteraturhistoriske sammenhænge og slægtskaber mellem forfatterskaber.

En anskuelse af lyrisk modernisme ud fra en transhistorisk og æstetisk-eksistentiel synsvinkel, som her har været fors $\emptyset \mathrm{gt}$, giver derimod muligheder for i højere grad at fokusere på essentielle sider ved nyere poesi. Frem for periodiseringer og regionalt eller idémæssigt afgrænsede grupperinger, vil det være mere frugtbart at anlægge diakrone litteraturhistoriske synsvinkler. Som et eksempel kan man med udgangspunkt i de fire lyrisk-modernistiske dimensioner opdele den samlede lyrik fra de sidste 150 år i tre hovedtraditioner.

Den første er en ekspansivt orienteret digtning eller ekspressionistisk skole, hvor digteren eksponerer sig selv og intonerer oprør og forandring. Repræsentanter er Whitman, Rimbaud, Lautréamont, Johannes V. Jensen, futuristerne, dadaisterne, Tom Kristensen, Rifbjerg, Ørnsbo, F.P. Jac, Carsten René Nielsen, Katrine Marie Guldager m. fl., og i centrum står konfrontationen mellen jeg og omverden (2. modernisme-dimension). Den anden er en syntesesøgende, kontemplativt orienteret digtning eller symbolistisk skole, hvor digteren skaber visionære særverdener, og hvor længslen går mod en opløsning af sub- 
jektet. Navne inden for denne retning er Stagnelius, Baudelaire, Trakl, Yeats, Södergran, Lindegren, Sarvig, Tafdrup, Annemette Kure Andersen etc. Essensen i denne type af digtning er det disharmoniske subjekt og længslen efter en alternativ tilstand (1. og 4. modernismedimension). Og den tredje en formorienteret digtning eller minimalistisk skole, hvor refleksioner i forhold til kunstbegrebet og sproget som materiale står i centrum. Vigtige digtere er her Mallarmé, Apollinaire, Valéry, imagisterne, Christian Morgenstern, Björling, Göran Palm, Højholt, Vagn Steen, Hans-Jørgen Nielsen, den tidlige Søren Ulrik Thomsen, Niels Frank, Lars Bukdahl etc. Grundintentionen er i dette tilfælde distraktionen i forhold til normalsproget samt skabelsen af et nyt, renset poetisk sprog (3. modernismedimension).

Den ovennævnte model er naturligvis kun én ud af mange måder at anskue og strukturere intertekstuelle sammenhænge i det tekstlandskab, som dansk og international modernistisk lyrik udgør. Andre kan med lige så stor ret opstilles, og er da også blevet det i de mange »linier « eller »traditioner «, som det i disse år er blevet comme il faut at opstille inden for dansk litteratur. ${ }^{86}$

Afgørende for, at man kan skabe meningsfulde litteraturhistoriske perspektiver, er imidlertid, at man læser modernistisk lyrik på dens egne betingelser. Hermed menes, at man ikke primært går på jagt $\mathrm{i}$ teksten efter ideologiske strukturer, psykoanalytiske symboler, kognitive skemaer eller retoriske figurer, men orienterer sig i forhold til tekstens intentionalitet og tager udgangspunkt i digterens kunstneriske projekt. Og dette projekt rammer man i hvert fald ikke helt ved siden af, hvis man taler om modernismens fire dimensioner.

\section{Noter}

1. Specielt kan man bemærke, at begrebet modernisme hovedsageligt har sin udbredelse i den nordiske og den angelsaksiske litteraturvidenskab. I den germanske litteraturkritik har begrebet haft en perifér status indtil 1980'erne, hvor det har fået omtrent samme betydning som i nordisk og angelsaksisk sammenhæng (modernismebegrebet findes dog også i tysksproget litteraturkritik tilbage til 1930ernes Lukács, hos hvem det dog blot nærmest er et skældsord). Endelig har ordet modernisme i de romanske sprog oftest en helt anden betydning end på de $\emptyset$ vrige sprog, idet det hentyder til en katolsk liberal, kritisk bevægelse, hvorfor modernismeforskningen i romansk sammenhæng i stedet ofte benytter betegnelsen »avantgardisme. «Som et resultat af de seneste års oversættelsesaktivitet tyder alt imidlertid på, at der sker en hastig terminologisk tilnærmelse sprogene imellem.

2. Peter Luthersson: Modernism och individualitet, Stockholm 1986, p.11. Overvejelserne over Luthersson stammer desuden fra Anne Borup: »Opbrud fra modernismen. En litteraturhistorisk unders $\varnothing$ gelse af opbrudstendenser i eksperimenterende dansk poesi fra 1965-74« (upubliceret arbejdspapir).

3. Af begrebshistoriske fremstillinger, der diskuterer betydningen af termen moderne i forskellige kontekster, kan nævnes Thorkild Borup Jensen: »Klassisk og moder- 
ne«, Tolkninger. Tekst og teori, Kbh. 1967; Paul de Man: »Literary History and Literary Modernity «, in Blindness and Insight, Minneapolis 1971; Per Stounbjerg: »Det ustadiges æstetik «, in LAES nr. 14, Århus 1991 og Peter Luthersson: Modernism och individualitet (se note 2).

4. Oplysningen stammer fra Poul Borum: Poetisk modernisme, Kbh. 1966.

5. Peter Kaspersen m.fl.: Spurvesol, bd.2, Kbh. 1989, p.212. Antologien er blot et blandt mange eksempler på en ganske ureflekteret brug af termen modernisme, hvor f.eks. tekster af Herman Bang og Gustav Wied placeres under modernisme, mens tekster af J.P. Jacobsen og Holger Drachmann af uransagelige årsager ikke tilkendes denne etikette, men derimod betegnelsen naturalisme.

6. Et opgør med opfattelsen af modernisme, som noget, der blot lader sig identificere som det til enhver tid nye - en bestemmelse, der bl.a. lanceres i Paul de Mans »Literary History and Literary Modernity«, og som forsvares i Pil Dahlerups »Hvad er modernisme? «, KRITIK 94, Kbh. 1991 - finder man i Peter Lutherssons Modernism och individualitet, der fremfører, at dyrkelsen af originaliteten som kvalitetskriterium langtfra er konstituerende træk ved modernismen som helhed.

7. Borum 1966, p.12 (se note 4).

8. Markante værker, der sætter skel mellem, hvad der kaldes modernismens 1., 2. og 3. fase, er Jørn Vosmar (red.): Modernismen i dansk litteratur, Kbh. 1967, og Hans-Jørgen Nielsen: Eksempler, Kbh.1968.

9. Poetisk modernisme er skarpsindig i sine nærlæsninger af tekster fra de henved 100 forfatterskaber fra hele den moderne vestlige kulturkreds, men svag med hensyn til at udfolde større perspektiver i modernismetraditionen. Når f.eks. Borum i et afsnit med titlen »Arabesker og dityramber « sætter J.P. Jacobsen og Lautréamont sammen, savner det saglig begrundelse, idet det næppe er muligt at se andre ligheder mellem Jacobsens kontemplative, naturmetaforiske arabesker og Lautréamonts rablende, tabukrænkende associationskæder, end at de begge skriver frie vers.

10. Graham Hough: »The Modernist Lyric«, in Malcolm Bradbury \& James McFarlane (eds.): Modernism. A guide to European Literature 1890-1930, London 1981 (org. 1976), p.314

11. Loc.cit.

12. Stounbjerg 1991, p. 8 (se note 3)

13. Loc.cit.

14. Det skal dog bemærkes, at begrebet romantik i stigende grad - fra og med H.M. Abrams The Mirror and the Lamp, Oxford 1953 og Northrop Fryes studier i den engelske romantik i 1950erne og frem til 1980ernes dekonstruktion (de Man, Hartman, Bloom, White etc) - har fået en bred og differentieret betydning, svarende til de mange forståelser af modernismebegrebet. Inden for nordisk forskning har man også i de sidste årtier kunnet iagttage et opbrud fra en opfattelse af romantikken som en periode, der kan bestemmes på grundlag af et idehistorisk indhold, og som unuanceret kan ses som en modsætning til f.eks. rationalisme eller naturalisme.

15. Malcolm Bradbury \& James McFarlane (eds.): Modernism, London 1981, p. 48

16. I det hele taget er det et generelt problem, at mange diskuterer de litterære termer modernisme og postmodernisme uden at overveje, hvorvidt disse begreber kan anskues løsrevet fra bestemte litterære genrer. Det gælder Pil Dahlerups »Hvad er modernisme? « (in Kritik 94, Kbh. 1991) (hvis opfattelse af, at i modernismen er »hverken transcendensen eller immanensen « tilstede, jeg absolut ikke deler (jvf. afsnittet »Den utopiske længsel«)), der udelukkende betjener sig af eksempler fra lyrikken, uden at der på nogen måde reflekteres over dette forhold. Det gælder 
Anne Mette Hejlsteds »Hinsides den glade nihilisme - eller om postmodernismen som æstetisk perspektiv« (in edda 4, Oslo 1995), der taler generelt om postmodernistisk litteratur, skønt emnet er en række amerikanske postmodernismeteorier, der specifikt vedrører prosa (Hutcheon, McHale, Wauch). Og det gælder Per Stounbjerg, der i »Det ustadiges æstetik « (se note 10) redegør for Strindbergs modernisme, uden at det diskuteres, hvorvidt de anvendte kategorier har samme betydning inden for lyrik som inden for prosa.

17. Man kan her blot bemærke, at langt den overvejende del af de værker, i hvis titel »modernisme« indgår, handler om henholdsvis lyrik og malerkunst.

18. Søren Baggesen: »Prosa«, in Jørn Vosmar (red.): Modernismen i dansk litteratur, Kbh. 1967, p.121.

19. Stounbjerg 1991, p.28.

20. Frank Kermode: »Modernisms«, Bernard Bergonzi (ed.): Innovations. Essays on Art and Ideas, London 1968

21. En årsag til denne distinktion er desuden, at man i visse litteraturkritiske værker, heriblandt Peter Bürgers toneangivende Theorie der Avantgarde (Frankfurt 1974), opererer med en modsætning mellem avantgardisme (surrealisme, dadaisme, futurisme og andre oprørske bevægelser, der bl.a. satser på en sprængning af det traditionelle værkbegreb og en afvisning af det etablerede samfund og kunstinstitutionen) og modernisme (den tradtionsbevidste højmodernisme med skikkelser som Eliot, Pound, Joyce etc.). Centralt i forhold hertil står også en række skarpt polemiserende artikler fra den amerikanske »minimalismedebat« fra slutningen af 1960erne og fremefter. Markante eksempler er her Michael Frieds »Art and Objecthood «, in Minimal Art. A Critical Antology, New York 1967, Craig Owens »The Allegorical Impuls. Towards a Theory of Postmodernism « (1980), in Brian Wallis (ed.): Arter Modernism (New York 1988) og Hal Fosters »Re: Post« (1982), ibid.

22. Torben Brostrøm: Anmeldelse af Strukturen i moderne lyrik, Information 19/7 1968, in Ti års kritik, p.74, Kbh. 1975.

23. Borum 1966, p.20 (se note 4).

24. Georg Brandes: Danske digterportratter, Kbh. 1981 (org. 1883), p. 276.

25. Erik A. Nielsen: Modernismen i dansk litteratur 1870-1970, Kbh. 1976, p. 28.

26. Peer E. Sørensen: »Den æstetiske abstraktion«, in Per Olsen (red.) Analyser af moderne dansk lyrik, Kbh. 1976, p.49.

27. Poul Borum: »Jacobsen mellem Mallarmé og Rimbaud«, in Thomas Bredsdorff (red.): Danske digtanalyser, Kbh.1969.

28. Jf. f.eks. Northrop Frye: A Study of English Romanticism, New York 1968, H.M. Abrams: The Mirror and the Lamp, Oxford 1953 og Paul de Man: The Rhetoric of Romanticism, New York 1984.

29. Bo Green Jensen: »Den stadige blomstring og den tabte epifani«, in Afstandens indsigt. Essays om litteratur 1980-84, Kbh. 1985, p.22.

30. Herbert Read: Art Now (1933), London 1960.

31. C.S. Lewis: They ask for a Paper, London 1962 (org. 1955), p.9-25.

32. Virginia Woolf: »Mr. Bennett and Mrs. Brown«, Collected Essays, Vol. 1, London 1966 (opr. 1924), p.324.

33. A. Alvarez: Beyond All This Fiddle. Essays, 1955-1967, London 1968 og Stephen Spender: The Struggle of the Modern, London 1963.

34. Kermode 1968 (se note 20)

35. Richard Ellmann: »The two Faces of Edward«, in Edwardians and late Victorians, New York 1960. 
36. Harry Levin: »What Was Modernism?« Refractions: Essays in Comparative Literature, London 1966.

37. Bradbury \& McFarlane 1991, p.52 (se note 15).

38. Loc.cit. p.51.

39. Loc.cit. p.52.

40. José Ortega y Gassét: Menneskets fordrivelse fra kunsten, Kbh. 1945 (org. 1925) p. 21,28 og 40.

41. Hugo Friedrich: Strukturen i moderne lyrik, Kbh. 1987 (org. 1956), p.8f.

42. Torben Brostrøm: Modernisme før og nu, Kbh. 1983, p.7.

43. Det skal nævnes, at der i dansk litteraturkritik findes forsøg på at opstille lignende kategorier i en generel bestemmelse af, hvad modernisme er. Eksempler er Erik Skyum-Nielsens »80'er-gespenstet. Om en tendens i ny dansk lyrik«, in Bogens Verden nr. 1, 1983; Niels Ole Finnemann: Modernismens erkendelsesteoretiske problematik, Grenå 1972; og Jørgen Lorenzen: Litteratur, Kbh. 1976.

44. Arthur Rimbaud: Lettres du voyant (1871), citeret efter Friedrich 1987, p.58.

45. Tom Kristensen: »Fribytter« og »Landet Atlantis«, in Fribytterdrømme, Kbh. 1920, og »Angst«, in Harvark, Kbh. 1930.

46. Klaus Rifbjerg: »Refshaleøen«, »Frihavnen« og »Jern«, in Konfrontation, Kbh. 1960.

47. Søren Ulrik Thomsen: Nye digte, Kbh. 1987 og Hjemfalden, Kbh. 1991.

48. Friedrich 1987, p.30 (se note 41).

49. Loc.cit. p.68.

50. T.S. Eliot: »Tradition and the Individual Talent«, in The Sacred Wood, London 1960 (org. 1920), p.100.

51. Pia Tafdrup: Over vandet går jeg, Kbh. 1991, p.10.

52. Loc.cit. p.38.

53. T.S. Eliot: »Hamlet and his Problems«, The Sacred Wood, London 1960 (org. 1920), p.100.

54. T.S. Eliot: »The Metaphysical Poets « (org. 1921), in Selected Essays, London 1969, p.289.

55. Carsten René Nielsen: »At leve drømmen. Interview med lyrikeren Lene Henningsen«, in Ildfisken nr.2, 1992, p.13.

56. En årsag til, at y Gassét i så høj grad betoner det antimimetiske, er, at hans værk stammer fra en tid (1925), hvor forestillingen om en abstrakt billedkunst ikke har mere end 15 år på bagen, hvorfor diskussionen af dette spørgsmål i er oppe i tiden. Man skal desuden bemærke, at y Gasséts essay i første række beskæftiger sig med billedkunst, hvor spørgsmålet om realisme (ligesom i prosaen) har en anderledes central plads i den æstetiske teoridannelse end inden for lyrikken.

57. Friedrich 1987, p.77 (se note 41).

58. Oversat af Rolf Gjedsted i En engel $i$ handerne på en barber, Kbh. 1991. Originalteksten lyder: »Comme je descendais des Fleuves impassibles,/ Je ne me sentis plus guidé par les haleurs: / Des Peaux-Rouges criards les avaient pris pour cibles, / Les ayant cloués nus poteaux de couleurs. // J'étais insoucieux de tous les équipages, / Porteur de blés flamands ou de cotons anglais. / Quand avec mes haleurs ont fini ces tapages, / Les Fleuves m’ont laissé descendre où je voulais«, Arthur Rimbaud: »Le Bateau ivre« (1871).

59. Thorkild Bjørnvig: »Intethed og form« (1960), in Begyndelsen. Essays, Kbh. 1960, p.80.

60. Loc. cit. p.85. 
61. Tafdrup 1991, p.79 (se note 51).

62. Arthur Rimbaud: »Ordets alkymi«, in Une Saison en Enfer (1873), oversat til dansk af Jørgen Sonne i De første moderne, Kbh. 1983 og af Poul Borum i Hugo Friedrich: Strukturen i moderne lyrik, Kbh. 1987.

63. Friedrich 1987, p.116.

64. Den »sproglige vending « inden for litteraturvidenskaben indledes med den russiske formalisme i 1920erne, hvor specielt Victor Shlovskys: »Kunsten som greb« (1916) er banebrydende, og videreudvikles fra slutningen af 1960erne inden for den franske poststrukturalisme (Derrida, Barthes) og den amerikanske dekonstruktion (de Man, Hartman, Bloom, White).

65. T.S. Eliot: »Burnt Norton V«, in Four Quartets, London 1943.

66. Jvf. f.eks. Bo Hakon Jørgensen og Jens Sand Sørensen: »Verset som organ«, in Sophus Claussen. En studiebog, Kbh. 1977, p.173f.

67. Hans-Jørgen Nielsen: Eksempler, Kbh. 1968, p. 162.

68. Vagn Steen: Laesninger, Kbh. 1969, p.19.

69. Per Højholt: Cézannes metode, Kbh. 1967, p.13 og 68.

70. En grundig redegørelse for denne problematik findes i Erik Skyum-Nielsen: Modsprogets proces, Kbh. 1981.

71. Søren Ulrik Thomsen: Mit lys brander. Omrids af en ny poetik, Kbh. 1985, p.18.

72. Loc.cit. p.19.

73. Loc.cit. p.24.

74. Friedrich 1987, p.43.

75. Thorkild Bjørnvig: »Moderniteten som holdning «, in Virkeligheden er til. Littercere essays, Kbh. 1973, p.246.

76. Bo Hakon Jørgensen: Symbolismen - eller jegets orfiske forklaring, Odense 1993, p.240.

77. Et nøglebegreb i Torben Brostrøms værker om lyrikken omkring 1960. Det benyttes specielt i Torben Brostøm: Klaus Rifbjerg, Kbh. 1970.

78. Tafdrup 1991, p.79 (se note 51).

79. Loc.cit. p.43.

80. Loc.cit. p.166.

81. Søren Ulrik Thomsen 1985, p.45 og p.145 (se note 71).

82. Bo Green Jensen: »Den stadige blomstring og den tabte epifani «, in Afstandens indsigt, Kbh. 1985, p.28.

83. Carsten René Nielsen: »At leve drømmen. Interview med lyrikeren Lene Henningsen«, in Ildfisken $\mathrm{nr} .2$, 1992, p.12.

84. Ezra Pound: ABC for laesere, Fredensborg 1960, p.36.

85. Udtrykket stammer fra Steffen Hejlskov Larsen: Systemdigtningen (Kbh. 1971).

86. At man i løbet af 1970erne og 1980erne i filosofi og litteraturvidenskab har antastet brugen af faste litteraturhistoriske konstruktioner, har naturligvis også haft indflydelse på dansk litteraturforskning, hvor det i stadig stigende grad er blevet legalt for den enkelte litterat at lave sin litteraturhistorie eller, som det ofte hedder, »linie« i dansk digtning. Inden for dansk lyrik finder man af eksempler på dette Erik A. Nielsens Modernismen i dansk lyrik 1870-1970, Kbh. 1976; Knud Wentzels Utopia. Et motiv i dansk lyrik, Kbh. 1990; Bo Hakon Jørgensens Symbolismen - eller jegets orfiske forklaring, Odense 1993; Klaus P. Mortensens Himmelstormerne. En linie i dansk naturdigtning, Kbh. 1993 og Søren Baggesens Seks sonderinger. Den panerotiske linie i dansk lyrik, Odense 1997). 